\title{
Effect of Juice Turbidity and Yeast Lees Content on Brandy Base Wine and Unmatured Pot-still Brandy Quality
}

\author{
F.P. van Jaarsveld ${ }^{1}$, M. Blom ${ }^{2}$, S. Hattingh ${ }^{3}$ and J. Marais ${ }^{1}$ \\ (1) ARC Infruitec-Nietvoorbij**, Private Bag X5026, 7599 Stellenbosch, South Africa \\ (2) Distell Pty Ltd., P.O. Box 184, 7599 Stellenbosch, South Africa \\ (3) Department of Medical Physiology, University of Stellenbosch, P.O. Box 19063, 7505 Tygerberg, South Africa
}

Submitted for publication: June 2005

Accepted for publication: October 2005

Key words: Juice turbidity, yeast lees content, brandy base wine (wine for brandy production), unmatured pot-still brandy, brandy quality, esters, acids, higher alcohols, Chenin blanc

\begin{abstract}
The aims of this project were to identify a suitable grape juice clarification technique for the attainment of the optimal brandy base wine turbidity, to determine the importance of chemical components (volatile components and long-chain fatty acids) in brandy base wine and unmatured pot-still brandy quality, and to study the effect of yeast lees content on quality. Although common industry practice is to use the grape cultivars Colombar(d) and Chenin blanc for the production of brandy base wine, the optimal conditions for Chenin blanc have been defined in this study. The juice clarification treatments applied included no settling, cold settling, whisk, large- and small-scale centrifugation and bentonite. Yeast strain 228 was compared with VIN13, large-scale (L) distillation was compared with small-scale (s) distillation, and the use of no enzyme was compared with the use of pectolytic enzyme. The data for four vintages were compiled and evaluated. Settling with or without pectolytic enzyme, bentonite, small-scale centrifugation and whisk treatments gave clearer Chenin blanc juice, higher concentrations of certain volatile components and long-chain fatty acids, and higher quality brandy base wine and unmatured pot-still brandy. No settling and large-scale centrifugation yielded the most turbid and lowest quality products. There is a definite relationship between treatments, turbidity, concentrations of esters, higher alcohols and acids, and overall brandy base wine and unmatured pot-still brandy quality. The use of yeast strain VIN13 (as opposed to strain 228), in conjunction with an increased yeast lees content of $1.5 \mathrm{x}$ that is normally found in brandy base wine, yielded the best quality unmatured pot-still brandy. Based on the results of this study, it is possible to recommend the best juice clarification method(s) for optimal turbidity as well as optimal levels of yeast lees addition, and to identify chemical compounds that positively relate to quality.
\end{abstract}

According to current guidelines, brandy base wine is prepared from juice that is not completely clear. Techniques for the clarification of juice differ between cellars. Variation in brandy base wine quality between techniques, as well as when using the same technique, occurs frequently. The most appropriate degree of turbidity will probably also differ between cultivars. It is therefore necessary to have proper guidelines concerning the appropriate degree of turbidity and the clarification technique(s) that will give rise to the best brandy base wine quality. Little is known about the impact that different juice clarification techniques might have on the concentrations or composition of long-chain fatty acids, esters, acids and higher alcohols, or the factors that might influence them under local conditions, i.e. viticultural practices, harvesting method, transport conditions, grape condition, juice composition, microbial content of grape juice, clarification method, brandy base wine making processes, conditions of alcoholic fermentation, type of yeast, levels of yeast lees, and processes of maturation. Knowledge of the concentrations and composition of these groups of components could lead to the production of brandy with a more complex character and even higher quality in the future.

Various juice clarification techniques are recorded in literature, including the use of bentonite, pectolytic enzyme (Withy et al., 1993), whisking (Venter, 1991), centrifugation (Hamatschek \& Nagel, 1993; Israel \& Leufstedt, 1993; Kern et al., 1993) and settling (Boivin et al., 1998; Venter, 1991). Bentonite is a natural clay mineral recovered from volcanic vitric tuff, the main component of which is montmorillonite, a hydroxylate of aluminium (Görtges \& Haubrich, 1992; Waters et al., 2000). It is commonly used in the clarification and stabilisation of juice/must and wine. Bentonite absorbs proteins (Blade \& Boulton, 1988; Waters et al., 2000; Mesquita et al., 2001), removes tannins/(poly)phenols (Servilli et al., 2000; Spagna et al., 2000; Gómes-Plaza et al., 2002; Gökmen et al., 2003) and reduces other defensive agents

\footnotetext{
* Corresponding author: E-mail address: VjaarsveldF@arc.agric.za

**The Fruit, Vine and Wine Institute of the Agricultural Research Council
}

Acknowledgements: The authors would like to thank the Agricultural Research Council and the South African Wine Industry (Winetech) for financial support, as well as Louwshoek Voorsorg Cellar (now Daschbosch Wine Cellar) for providing grape juice and the whisking and large-scale centrifugation of samples. Special thanks go to Morné Lamont for the statistical analyses of data and to Carin de Wet for the necessary typing and electronic composition of tables. 
found in plants, as well as biogenic amines (Görtges \& Haubrich, 1992), due to its absorbant cation-exchange and precipitation ability. By acting on pectin, the pectinases reduce the viscosity of grape juice and cause cloud particles to aggregate into larger units, which sediment, and are removed easily by settling, thus improving the clarification and stabilisation of juice and wine. During centrifugation the centrifugal force forces solids to sediment out of solution, thus reducing the solids content and clarifying the juice. During whisking (pumping with simultaneous aeration of juice), proteins and various other components (including phenols) are denatured to varying degrees, causing them to break up and/or polymerise, thus effectively separating out of solution and yielding a less turbid juice. Settling of juice allows the heavier particles to precipitate out of solution, thus effectively yielding a less turbid juice.

Both major and minor components are responsible and necessary for the total brandy aroma. Esters, higher alcohols (Pons \& Wild, 1991; Lambrechts \& Pretorius, 2000), acids (Nykänen et al., 1968) and carbonyl compounds (Lau et al., 1999; Lambrechts \& Pretorius, 2000; Marchand et al., 2000) make important contributions to the aroma profile and quality of brandy (Schaefer \& Timmer, 1970; Wagener, 1986; Piggot et al., 1992). The term higher alcohols (also known as fusel alcohols) refers to those alcohols with a higher molecular mass and boiling temperature than ethanol, and which serve as important precursors for ester formation. Esters form one of the largest and most important groups of aroma components in wine (Lambrechts \& Pretorius, 2000). Most of the fatty acids present in alcoholic products are straight-chain saturated fatty acids with an even number of carbon atoms. Short-chain fatty acids are one of the factors that, together with ethanol, play an important part in the inhibition of yeasts (Calull et al., 1991). Since not all components play an organoleptically positive role and can cause "off tones" (Di Cesare et al., 1991), one of the aims of this study was to identify those components that correlate positively with overall quality.

The aims of this project were to test the effect of Chenin blanc juice turbidity on brandy base wine quality and unmatured potstill brandy quality, and recommend one or more appropriate juice clarification technique(s) accordingly, as well as to determine the importance of long-chain fatty acids, esters, acids and higher alcohols, and the effect of yeast lees content on these compounds and quality.

\section{MATERIALS AND METHODS}

\section{Harvest and processing of Chenin blanc grapes and juices}

Brandy base wines in this study qualified as base wines. Good brandy base wine has to meet certain criteria in order to ensure a good quality unmatured pot-still brandy (Wagener, 1986; Venter, 1991). Grape juice from the same cultivar (i.e. Chenin blanc) and from the same cellar was used over four seasons (1997-2000) for the purpose of this study, and was subjected to different treatments. Cultivar was, therefore, not a variable considered. Chenin blanc juice $(3400 \mathrm{~L})$ was obtained from Louwshoek Voorsorg Cellar, Rawsonville, transported in tanks by road to Nietvoorbij cellar, and divided into portions, each of which was subjected to a different juice clarification method, i.e. no settling (control), settling with and without pectolytic enzyme, bentonite addition, and small-scale centrifugation. Grape juice (1500 L) was also centrifuged on large-scale (4000 rpm) at Louwshoek Cellar. Juices that received no settling treatment, as well as small- and large-scale centrifuged juices, were inoculated immediately with VIN13 and 228. In practice, centrifuged juice is usually not settled before centrifugation. Settling, bentonite- and pectolyticenzyme-treated juices were settled overnight at $18^{\circ} \mathrm{C}$ (Snyders, 1989) before inoculation. Whisking was done at the Louwshoek Cellar, and the whisked, but unsettled, juice (1500 L) was transported to Nietvoorbij, where the juice was settled overnight at $18^{\circ} \mathrm{C}$ before inoculation. Brandy base wines from fermented juices that had undergone all types of treatments described above were distilled on a small-scale (5-L volumes), whereas largescale distillation (in 180-L pot-stills) was only performed on wines resulting from juices subjected to no settling, settling with pectolytic enzyme, whisking and large-scale centrifugation treatments. Two yeast strains (VIN13 and 228) were used for each small-scale treatment, whereas only yeast 228 was used in largescale treatments. Diammonium phosphate $(50 \mathrm{~g} / \mathrm{L})$ was added to all juices. All treatments were done in duplicate. For small-scale treatments, grape juices were pumped to smaller tanks for suitable treatment and to 20-L canisters for inoculation and fermentation, and later distilling of brandy base wine in 5-L quantities (3 $\mathrm{g}$ of copper sulphate and two copper plates were added to the wine to emulate the effect of copper). For large-scale treatments, juices were pumped to 170 -L tanks for suitable treatments, inoculation and fermentation, and later distillation was carried out in 180-L pot-stills at Nietvoorbij. Small-scale distillation with laboratory apparatus, according to the Méthode Charentaise (Léauté, 1990), avoided the high costs associated with commercial-scale experiments. Double distillation was used to emulate legal practice in South Africa. Distillations on a larger scale, in 180-L copper pot-stills at the Nietvoorbij distillery, were performed to compare results from large-scale treatments (approximating a situation closer to that in practice) with those of small-scale treatments, and thus verify the successful application on a commercial scale.

All brandy base wines were left on the yeast lees, and mixed thoroughly before distilling to pot-still brandy. During distillation, as in wine maturation taking place on the lees, yeast autolysis takes place and various components are released into the medium (Ibern-Gómez et al., 2000).

Pectolytic enzymes were included as treatment from the 1998 harvest year, since various cellars that produce brandy base wine use pectolytic enzyme in conjunction with settling treatment.

\section{Measuring of juice turbidity}

Juice turbidity was determined using a turbidity meter (Klett units), as well as spectrophotometrically at $420 \mathrm{~nm}$.

\section{Effect of yeast lees addition}

In a separate experiment, the effect that the addition of different concentrations of yeast lees to brandy base wine has on wine and unmatured pot-still brandy quality, and volatile and fatty acid component concentrations, was studied using only one clarification method, i.e. settling. This part of the research only commenced in the 1999 season. Chenin blanc grape juice was settled overnight at the Louwshoek Voorsorg Cellar and the clear juice was then transported to Nietvoorbij where each juice was divided into two equal $600-\mathrm{L}$ portions and inoculated separately with 
yeast strains 228 and VIN13. After fermentation, the wine was racked and the ratio of wine to yeast lees determined. Different ratios of yeast lees were added back to the corresponding wine (20 L), i.e. no yeast lees addition (control), 1x, 1.5x, and 2x yeast lees (all experiments were carried out in duplicate). Brandy base wines (together with yeast lees) were distilled approximately one month later. The unmatured pot-still brandies were analysed for esters, higher alcohols and long-chain fatty acids, and also evaluated sensorially.

\section{Sensory evaluation}

Brandy base wines were sensorially evaluated in duplicate for aroma on nose, flavours on taste, fullness of flavour and overall quality by a panel of experienced judges. A line method was used, i.e. evaluating the wine characteristics, by making a mark on an unstructured, straight $10-\mathrm{cm}$ line. The left-hand and right-hand ends of the line were indicated respectively by the terms, "non descriptive" and "complex" for aroma (nose), "flavourless" and "full flavoured" for aroma (taste), "extremely light" and "full" for body (or "hard" and "soft" in the case of unmatured pot-still brandy; Venter, 1994), and "low" and "high" for overall quality. Unmatured pot-still brandy samples were sent out in glass bottles to the industry where they were evaluated by industry experts with extensive experience in the sensory evaluation of brandy base wine and unmatured pot-still brandy. It must be noted that the characteristic "fullness" in unmatured pot-still brandy was replaced with "hardness", since hardness can already manifest itself in an unmatured distillate. It was argued that fullness only manifests later in the wood-matured product (the sensation of hardness can, however, change during the course of wood maturation when the effects of astringent tannins are added to the socalled hot, hard spirit character). In both cases (brandy base wine and unmatured pot-still brandy) the repeatability of the judges was subjected to statistical evaluation. Although statistical differences existed between tasters, the consistency of tasters within harvest years was good. The sensory data of all tasters were taken into account in the results.

\section{Determination of volatile components}

Volatile components were determined using gas chromatography (GC), after extraction from brandy base wines and unmatured pot-still brandy according to Distell Pty. Ltd. laboratory method no. CAM 77. The GC (HP 5890 series II) conditions were as follows: injection port temperature $200^{\circ} \mathrm{C}$; flame ionisation detector (FID) temperature $250^{\circ} \mathrm{C}$; oven temperature $200^{\circ} \mathrm{C}$ to $250^{\circ} \mathrm{C}$ and a heating rate of $3^{\circ} \mathrm{C} / \mathrm{min}$; hydrogen flow rate $30 \mathrm{ml} / \mathrm{min}$; split ratio 20:1. The column used was an Innowax (60 m x $0.25 \mathrm{~mm}$ x $0.5 \mu \mathrm{m}$ film thickness).

\section{A) Extraction of volatile components in brandy base wine}

Four milliliters of internal standard (4-methyl-2-pentanol, 464 $\mathrm{mg} / 2 \mathrm{~L}$ in $10 \%$ ethanol/water) was added to $50 \mathrm{ml}$ brandy base wine in a volumetric flask. The solution was transferred to a 250$\mathrm{ml}$ round-bottom flask, and then $30 \mathrm{ml}$ ether was added. Extraction followed on a rotary evaporator for 30 minutes at 60 $\mathrm{rpm}$. The top layer was drawn off using a Pasteur pipette, transferred to a GC vial, and analysed as noted above. The volatile components were then determined by GC. The wine standard was provided by Distillers Corporation (Pty) Ltd and contained the following compounds: diethyl succinate $(2.49 \mathrm{mg} / \mathrm{L})$, ethyl acetate $(30.04 \mathrm{mg} / \mathrm{L})$, ethyl butyrate $(5.05 \mathrm{mg} / \mathrm{L})$, ethyl caprate $(2.30 \mathrm{mg} / \mathrm{L})$, ethyl caprylate $(2.50 \mathrm{mg} / \mathrm{L})$, ethyl caproate $(2.50$ $\mathrm{mg} / \mathrm{L})$, ethyl lactate $(10.01 \mathrm{mg} / \mathrm{L}), 2$-phenyl ethyl acetate $(2.50$ $\mathrm{mg} / \mathrm{L})$, hexyl acetate $(2.50 \mathrm{mg} / \mathrm{L})$, isoamyl acetate (3-methylbutyl acetate) (2.51 mg/L), 2-phenyl ethanol (10.05 mg/L), n-hexanol (2.50 mg/L), isoamyl alcohol (3-methyl-1-butanol) $(60 \mathrm{mg} / \mathrm{L})$, isobutanol (2-methyl-1-propanol) $(7.53 \mathrm{mg} / \mathrm{L})$, methanol (29.99 $\mathrm{mg} / \mathrm{L})$, n-butanol (2.51 mg/L), n-propanol (49.94 mg/L), acetic acid $(87.31 \mathrm{mg} / \mathrm{L}), \mathrm{n}$-capric acid $(5.00 \mathrm{mg} / \mathrm{L})$, n-caproic acid (4.99 mg/L), isobutyric acid (2-methyl-butyric acid) $(2.50 \mathrm{mg} / \mathrm{L})$, isovaleric acid (3-methylbutyric acid) $(2.52 \mathrm{mg} / \mathrm{L}), \mathrm{n}$-butyric acid (2.52 mg/L), n-valeric acid (2.52 mg/L), n-caprylic acid $(5.00$ $\mathrm{mg} / \mathrm{L})$ and propionic acid $(2.51 \mathrm{mg} / \mathrm{L})$.

\section{B) Determination of the volatile components in unmatured pot- still brandy}

Samples were injected directly into the GC column. The internal standard used was 4-methyl-2-pentanol $(200 \mathrm{mg} / 100 \mathrm{ml}$ in $70 \%$ ethanol). Fifty microlitres of internal standard was added to 1000 $\mu \mathrm{l}$ unmatured pot-still brandy. The standard solution was prepared using the following compounds in $70 \%$ ethanol at specific concentrations approximating actual levels in $70 \%$ unmatured pot-still brandy: 1, ethyl acetate $(60 \mathrm{mg} / \mathrm{L}) ; 2$, ethyl butyrate (5 mg/L); 3, n-propanol (30 mg/L); 4, isobutanol (100 mg/L); 5 , isoamyl acetate $(10 \mathrm{mg} / \mathrm{L}) ; 6, \mathrm{n}$-butanol $(2 \mathrm{mg} / \mathrm{L}) ; 7$, internal standard (95 mg/L); 8, isoamyl alcohol (200 mg/L); 9, ethyl caproate $(200 \mathrm{mg} / \mathrm{L}) ; 10$, hexyl acetate $(1 \mathrm{mg} / \mathrm{L}) ; 11$, ethyl lactate (20 mg/L); 12, n-hexanol (200 mg/L); 13, ethyl caprylate $(5 \mathrm{mg} / \mathrm{L}) ; 14$, acetic acid $(100 \mathrm{mg} / \mathrm{L}) ; 15$, isobutyric acid $(5 \mathrm{mg} / \mathrm{L})$; 16 , ethyl caprate $(4 \mathrm{mg} / \mathrm{L}) ; 17$, diethyl succinate $(3 \mathrm{mg} / \mathrm{L}) ; 18,2$ phenylethyl acetate $(0.5 \mathrm{mg} / \mathrm{L}) ; 19$, n-caproic acid (5 mg/L); 20, 2 phenyl ethanol (5 mg/L); 21, n-caprylic acid (10 mg/L); 22, ncapric acid $(10 \mathrm{mg} / \mathrm{L})$.

\section{Long-chain fatty acid determinations in unmatured pot-still brandy}

Long-chain fatty acids were determined by use of GC. Different long-chain fatty acid extraction methods were used (see below). Long-chain fatty acids were initially (for two vintages) extracted by a more extensive method, using diethyl ether as extracting agent, then by a direct injection method (one vintage), and by a shortened extraction method using n-pentane (one vintage) according to the Distell Pty. Ltd. laboratory method no. CAM 76 (slightly adapted). Each extraction method made use of an internal standard and standard solution, and its own calibration curve against which test samples were determined.

\section{Extraction of unsaturated long-chain fatty acids in unmatured pot-still brandy: Method 1:}

Unmatured pot-still brandy $(50 \mathrm{ml})$ was measured precisely and poured into a round-bottom flask, followed by the addition of the internal standard pentadecanoic acid to a final concentration of 20 $\mathrm{mg} / \mathrm{L}$. The solution was evaporated to $30 \mathrm{ml}(27.0 \mathrm{~g})$ at $60 \mathrm{rpm}$ in a water bath, set at $35^{\circ} \mathrm{C}$. The $\mathrm{pH}$ of the $30 \mathrm{ml}$ pot-still brandy concentrate was adjusted to $\mathrm{pH} 3.0$, using formic (methanoic) acid. SEPPAK columns were conditioned with $5.0 \mathrm{ml}$ methanol using a 12-port solid-phase extraction vacuum manifold, followed by $30 \mathrm{ml}$ pot-still brandy and $5 \mathrm{ml}$ distilled $\mathrm{H}_{2} \mathrm{O}$ (left to dry), elution in a reaction flask with $5 \mathrm{ml}$ chloroform/methanol $(1: 1)$, and evaporated under nitrogen in a water bath at $46^{\circ} \mathrm{C}$. Two 
millilitres of a sulphuric acid/methanol (5:95) mixture was added to the flask, which was then placed in an oven for 2 hours at $70^{\circ} \mathrm{C}$ for methylation to occur. The contents of the reaction flask were transferred to a volumetric flask and made up to $50 \mathrm{ml}$ using distilled water. This solution was poured into a round-bottom flask and extracted with $30 \mathrm{ml}$ diethyl ether at room temperature, using a rotary evaporator at $60 \mathrm{rpm}$, for 30 minutes. The ether was drawn off into a marked pear-shaped flask and concentrated to $2 \mathrm{ml}$ by placing the flask, with a reflux column attached, in a water bath at $55^{\circ} \mathrm{C}$. Three microlitres of the concentrate was injected into the gas chromatograph.

\section{Extraction of unsaturated long-chain fatty acids in unmatured pot-still brandy: Method 2:}

The internal standard was prepared by weighing off $1 \mathrm{~g}$ of pentadecanoic acid $\left(\mathrm{C}_{15}\right)$, and making it up to $300 \mathrm{ml}$ with an $80 \%$ ethanol/water solution. For the standard solution, individual solutions were initially prepared for lauric acid $\left(\mathrm{C}_{12}\right)$, myristic acid $\left(\mathrm{C}_{14}\right)$, palmitic acid $\left(\mathrm{C}_{16}\right)$ and stearic acid $\left(\mathrm{C}_{18}\right)$ by dissolving $1 \mathrm{~g}$ of each in $50 \mathrm{ml}$ of absolute ethanol $(1 \mathrm{ml}=20 \mathrm{mg})$. The individual solutions were stored at $4{ }^{\circ} \mathrm{C}$ and, when needed, $0.25 \mathrm{ml}$ of each solution was added to $70 \%$ ethanol in a $50-\mathrm{ml}$ volumetric flask. Calibration values were $100 \mathrm{mg} / \mathrm{L}$ for each. The extraction was done by using $50 \mathrm{ml}$ of the standard solution or unmatured pot-still brandy and adding $1 \mathrm{ml}$ internal standard (calibration = $200 \mathrm{mg} / \mathrm{L}$ ), pouring the sample into a test tube, adding $30 \mathrm{ml} \mathrm{n}$ pentane (Riedel-de Haën - 32203), and extracting the sample by rotating it for 30 minutes at $60 \mathrm{rpm}$ using a rotator (Labinco). The n-pentane phase was drawn off and used to fill two crimp-top vials. The sample was injected into the GC column using an autosampler.

\section{Statistical analyses}

The variables measured were subjected to Analysis of Variance (ANOVA). The ANOVA showed a significant difference between the five treatments $(\mathrm{p}<0.05)$. Fishers Smallest Significant Difference method (SSD) was used to determine which treatment differed significantly at the $5 \%$ level. The data were also subjected to correlation analyses. Significant differences are indicated as $p \leq 0.05$, whilst insignificant differences are indicated as $p \geq 0.05$. The statistical computation of data was done with $\mathrm{SAS}=$ Statistical Analyses System (SAS edition 8.2).

\section{RESULTS AND DISCUSSION}

\section{General}

Sensory evaluation data are presented in Tables 1 and 2. In cases where sensory data from all harvest years were combined, great variation was found, as expected (see Tables 1 and 2). Chemical data are presented in Tables 3, 4 and 5. One example each of an ester, an alcohol, a fatty acid and an unsaturated fatty acid and their relationships with brandy base wine and unmatured pot-still brandy quality are illustrated in Figures 1 to 4 . Datasets for brandy base wine and unmatured pot-still brandy were computed separately, as reflected in the tables and figures.

\section{Effect of treatment on turbidity and overall quality}

Treatments that delivered clearer juices also yielded the highest quality brandy base wine and unmatured pot-still brandy. On the other hand, treatments that delivered the most turbid juices yielded the lowest quality products.
The following juice clarification techniques delivered the clearest and highest overall quality brandy base wine and unmatured pot-still brandy (see Tables 1 to 5 and Figures 1 to 4 ):

- Settling with and without pectolytic enzyme treatment [especially VIN13 fermented juice, settling (-P) VIN13 (s) and settling (+P) VIN13 (s)]

- Bentonite treatment [bentonite VIN13 (s), bentonite 228 (s)]

- Small-scale centrifugation [especially small-scale centrifugation VIN13 (s)]

Although whisk treatment [whisk VIN13 (s), whisk 228 (s) and whisk 228 (L)] delivered good quality brandy base wine [especially whisk VIN13 (s) and whisk 228 (s)], the corresponding unmatured pot-still brandy was of average quality.

The following juice clarification techniques delivered the most turbid juice and lowest overall quality brandy base wines and unmatured pot-still brandy (see Tables 1 to 5 and Figures 1 to 4):

- No settling for small-scale and large-scale distillation and using both yeast strains [no settling 228 (L), no settling 228 (s) and no settling VIN13 (s)]

- Large-scale centrifugation for small-scale as well as large-scale distillation and both yeast strains [large-scale centrifugation VIN13 (s), large-scale centrifugation 228 (s), large-scale centrifugation $228(\mathrm{~L})]$

\section{Effect of yeast lees concentration}

Although different levels of VIN13 yeast lees additions [1x, 1.5x, 2x yeast lees VIN13 (s)] to brandy base wine did not fare very well sensorially (also worse than yeast strain 228), the corresponding unmatured pot-still brandies were of a higher quality than yeast strain 228. Yeast strain 228 therefore gave higher quality brandy base wine than yeast strain VIN13 but VIN13, in turn, delivered higher quality unmatured pot-still brandy. When considering the overall yeast lees levels, and yeast strain 228 is compared with VIN13, statistically significant differences in quality can be observed for brandy base wines ( $\mathrm{p} \leq 0.05)$, but not for unmatured pot-still brandy ( $\mathrm{p} \geq 0.05$ ) (data not shown). In unmatured pot-still brandy the quality generally improved with increasing yeast lees content for both yeast strains (the opposite tendency was observed in brandy base wine). In the case of VIN13, the optimum yeast lees content, with regard to unmatured pot-still brandy quality, was with the addition of $1.5 \mathrm{x}$. In studying the effect of yeast lees concentration, the quality of the base wine is less important. Yeast lees serves to preserve the base wine during storage, but it has the greatest impact on the composition and quality of the pot-still distillate produced.

\section{Effect of yeast strain}

Brandy base wine and unmatured pot-still brandy from juice inoculated with VIN13 had a higher quality than when inoculated with 228 for nearly all of the treatments (see Tables 1 and 2 and Figures 1 to 4 ). When comparing all these treatments overall for VIN13 and 228, no differences were observed for brandy base wines ( $\mathrm{p} \geq 0.05)$, but a significant difference existed for unmatured pot-still brandy ( $\mathrm{p} \leq 0.05)$ (data not shown).

\section{Large- vs. small-scale distillation}

When comparing large-scale (L) and small-scale (s) distillation, the following tendencies were observed (see Tables 1 and 2 and Figures 1 to 4$)$ : 
- No settling 228 (L) yielded higher quality than no settling 228 (s) ( $\mathrm{p} \leq 0.05$ for brandy base wine and $\mathrm{p} \geq 0.05$ for unmatured pot-still brandy)

- Settling (+P) $228(\mathrm{~s})$ yielded higher quality than settling $(+\mathrm{P})$ $228(\mathrm{~L})$ ( $\mathrm{p} \geq 0.05$ for unmatured pot-still brandy and $\mathrm{p} \leq 0.05$ for brandy base wine)

- Whisk 228 (L) yielded higher quality unmatured pot-still brandy than whisk 228 (s) ( $\mathrm{p} \geq 0.05$ ), but a lower quality brandy base wine $(\mathrm{p} \leq 0.05)$

- Large-scale centrifugation 228 (s) yielded higher quality unmatured pot-still brandy than large-scale centrifugation 228 (L) (p $\geq 0.05$ ), but lower quality brandy base wine $(\mathrm{p} \geq 0.05)$

Differences between the above individual treatments for largescale distillations, as compared with small-scale distillations, for unmatured pot-still brandy were negligible (ultimately the unmatured pot-still brandy is closest to final brandy quality). Overall, when comparing the above-mentioned large-scale and smallscale distillations for both brandy base wine and unmatured potstill brandy, it is clear that the scale of distillation does not have a significant impact on quality ( $\mathrm{p} \geq 0.05$ ) (data not shown).

\section{Large- vs small-scale centrifugation}

When small-scale centrifugation (9000 rpm) is compared with large-scale centrifugation (4000 rpm), the following tendencies were observed in both brandy base wine and unmatured pot-still brandy (see Tables 1 and 2 and Figures 1 to 4):

- Small-scale centrifugation VIN13 (s) yielded higher quality than large-scale centrifugation VIN13 (s) ( $\mathrm{p} \geq 0.05$ in unmatured pot-still brandy and $\mathrm{p} \leq 0.05$ in brandy base wine)

- Small-scale centrifugation 228 (s) yielded higher quality than large-scale centrifugation 228 (s) ( $\mathrm{p} \leq 0.05$ in unmatured potstill brandy and $\mathrm{p} \leq 0.05$ in brandy base wine)

Overall, it was observed that large-scale centrifugation, for both brandy base wine and unmatured pot-still brandy, delivered more turbid juice and significantly lower quality than small-scale centrifugation $(\mathrm{p} \leq 0.05)$. Quality differences were clearly coupled to turbidity levels, which varied with centrifugation speed.

\section{Effect of pectolytic enzyme treatment}

When treatments with and without pectolytic enzyme are compared, the following tendencies were observed (see Tables 1 and 2 and Figures 1 to 4 ):

- Settling (-P) VIN13 (s) yielded higher quality unmatured potstill brandy, but lower quality brandy base wine than settling (+P) VIN13 (s) (p $\geq 0.05$ for brandy base wine and unmatured pot-still brandy)

- Settling (+P) 228 (s) yielded higher quality than settling (-P) 228 (s) ( $\mathrm{p} \geq 0.05$ for brandy base wine and unmatured pot-still brandy)

The degree of difference between turbidity and quality for all treatments, with or without pectolytic enzyme, and for both brandy base wine and unmatured pot-still brandy, are insignificantly small ( $\mathrm{p} \geq 0.05$ ) (data not shown).

Chenin blanc brandy base wine and unmatured pot-still brandy quality did not benefit much from the enzymatic treatments of the juice since this cultivar can settle spontaneously. The results of this study confirm the findings of Rabbets (1989) and prove the importance of pre-trials before pectolytic enzymes are used for the standard treatment of juice. The use of pectolytic enzymes led to small, but insignificant, quality improvements. An observable increase in methanol levels (within acceptable and permitted limits) was also brought about by the use of pectolytic enzyme.

\section{Effect of treatment method on concentrations of flavour com- pounds and quality}

Undistilled and distilled beverages contain alcohols, esters and free fatty acids (Nykänen et al., 1968) (see Tables 3 to 5). There is a definite relationship between treatment, concentrations of some of the volatile and non-volatile compounds, and overall brandy base wine and/or unmatured pot-still brandy quality (see Figures 1 to 4 ). Treatments that yielded higher concentrations of the above compounds (in the case of positive correlations) also yielded the highest quality products. In the case of negative correlations, treatments that resulted in higher quality products yielded lower concentrations of the above compounds.

Significant positive $(\mathrm{p} \leq 0.05)$ correlations were found between brandy base wine quality and the following volatile compounds: ethyl butyrate, ethyl caprate, ethyl caprylate, ethyl acetate, hexyl acetate, isoamyl acetate, n-butanol, n-capric acid, n-butyric acid, n-caprylic acid (see Table 6), ethyl caproate (see Figure 1) and ncaproic acid (see Figure 3).

Significant negative $(\mathrm{p} \leq 0.05)$ correlations were found between brandy base wine quality and the following volatile compounds: 2-phenyl ethanol, isoamyl alcohol, isobutanol (see Table 6) and hexanol (see Figure 2).

Significant positive $(\mathrm{p} \leq 0.05)$ correlations were found between unmatured pot-still brandy quality and the following volatile compounds: acetoin, ethyl acetate, hexyl acetate, isoamyl acetate, n-butanol, n-capric acid, n-caprylic acid (see Table 6), ethyl caproate (see Figure 1) and n-caproic acid (see Figure 3).

Significant negative $(\mathrm{p} \leq 0.05)$ correlations were found between unmatured pot-still brandy quality and the following volatile compounds: isoamyl alcohol, isobutanol (see Table 6) and hexanol (see Figure 2).

With regard to the long-chain fatty acids, a significant positive correlation ( $\mathrm{p} \leq 0.05)$ was observed for lauric acid $\left(\mathrm{C}_{12}\right)$ only (see Figure 4). Lauric acid has the shortest chain and is therefore the most hydrophilic of the long-chain fatty acids studied.

No settling and large-scale centrifugation treatments that delivered products with the lowest overall quality were shown to have some of the highest total higher alcohol concentrations. The negative correlation between quality and higher concentrations of higher alcohols (except for n-butanol) was confirmed by earlier studies (Wagener, 1986). Isoamyl alcohol showed a negative correlation with quality, which supports the results of trials in which it was found that this compound has the ability to influence the taste of wines (Lambrechts \& Pretorius, 2000). No correlation was observed between propanol and overall quality, which supports similar findings by other authors (Lambrechts \& Pretorius, 2000). The levels of hexanol for Chenin blanc in this study were close to the threshold values of several $\mathrm{mg} / \mathrm{L}$ (Kotseridis et al., 1998). Hexanol gives a herbal aroma to wines and correlates negatively with overall quality (see Figure 2). This study also confirmed the finding of Wagener (1986) that methanol does not play a role as indicator of quality. 
TABLE 1

Brandy base wine evaluation data (1997-2000 seasons).

\begin{tabular}{|c|c|c|c|c|c|c|c|c|}
\hline \multirow{2}{*}{ Treatment } & \multicolumn{2}{|c|}{$\begin{array}{c}\text { Aroma (nose) } \\
(\%)\end{array}$} & \multicolumn{2}{|c|}{$\begin{array}{c}\text { Aroma (taste) } \\
(\%)\end{array}$} & \multicolumn{2}{|c|}{$\begin{array}{c}\text { Fullness/Body } \\
(\%)\end{array}$} & \multicolumn{2}{|c|}{$\begin{array}{l}\text { Overall quality } \\
\qquad(\%)\end{array}$} \\
\hline & $\mathbf{N}$ & $\begin{array}{l}\text { Average } \\
\text { (SD) }\end{array}$ & $\mathbf{N}$ & $\begin{array}{l}\text { Average } \\
\text { (SD) }\end{array}$ & $\mathbf{N}$ & $\begin{array}{l}\text { Average } \\
\text { (SD) }\end{array}$ & $\mathbf{N}$ & $\begin{array}{l}\text { Average } \\
\text { (SD) }\end{array}$ \\
\hline No settling 228 (s) & 64 & $\begin{array}{c}44.5^{\mathrm{kl}} \\
(25.52)\end{array}$ & 60 & $\begin{array}{c}44.4^{\mathrm{jk}} \\
(26.35)\end{array}$ & 60 & $\begin{array}{l}51.9^{\text {cdefghi }} \\
(23.46)\end{array}$ & 64 & $\begin{array}{c}34.9^{\mathrm{m}} \\
(25.23)\end{array}$ \\
\hline No settling VIN13 (s) & 61 & $\begin{array}{l}44.9^{\mathrm{jkl}} \\
(23.57)\end{array}$ & 59 & $\begin{array}{l}48.9^{\text {ghij }} \\
(23.59)\end{array}$ & 59 & $\begin{array}{c}53.1^{\text {bcdefg }} \\
(22.31)\end{array}$ & 63 & $\begin{array}{l}38.41^{\mathrm{m}} \\
(26.10)\end{array}$ \\
\hline No settling 228 (L) & 64 & $\begin{array}{l}49.8^{\mathrm{ghi}} \\
(21.69)\end{array}$ & 64 & $\begin{array}{l}51.2^{\text {fghi }} \\
(23.48)\end{array}$ & 64 & $\begin{array}{l}53.7^{\text {bcdefg }} \\
(22.09)\end{array}$ & 64 & $\begin{array}{l}42.6^{\mathrm{jkl}} \\
(23.93)\end{array}$ \\
\hline Settling (-P) 228 (s) & 64 & $\begin{array}{l}54.9^{\mathrm{def}} \\
(16.26)\end{array}$ & 64 & $\begin{array}{l}53.9^{\text {defg }} \\
(17.71)\end{array}$ & 64 & $\begin{array}{l}50.2^{\text {fghij }} \\
(18.05)\end{array}$ & 64 & $\begin{array}{c}53.0^{\text {cdefg }} \\
(17.74)\end{array}$ \\
\hline Settling (-P) VIN 13 (s) & 64 & $\begin{array}{l}59.7^{\mathrm{abc}} \\
(18.72)\end{array}$ & 64 & $\begin{array}{l}58.6^{\mathrm{abcd}} \\
(17.29)\end{array}$ & 64 & $\begin{array}{c}56.6^{\text {abcde }} \\
(15.97)\end{array}$ & 64 & $\begin{array}{l}56.8^{\mathrm{bcd}} \\
(18.53)\end{array}$ \\
\hline Settling $(+\mathrm{P}) 228(\mathrm{~s})$ & 50 & $\begin{array}{l}55.0^{\mathrm{def}} \\
(15.12)\end{array}$ & 50 & $\begin{array}{c}56.9^{\text {abcde }} \\
(16.49)\end{array}$ & 50 & $\begin{array}{c}54.1^{\text {bcdefg }} \\
(16.59)\end{array}$ & 50 & $\begin{array}{c}54.3^{\text {bcdef }} \\
(17.13)\end{array}$ \\
\hline Settling (+P) VIN 13 (s) & 50 & $\begin{array}{c}58.2^{\text {abcde }} \\
(17.95)\end{array}$ & 50 & $\begin{array}{c}56.1^{\text {bcdef }} \\
(19.67)\end{array}$ & 50 & $\begin{array}{l}54.4^{\text {bcdegf }} \\
(19.98)\end{array}$ & 50 & $\begin{array}{l}57.1^{\text {bcd }} \\
(21.37)\end{array}$ \\
\hline Settling (+P) $228(\mathrm{~L})$ & 64 & $\begin{array}{l}56.4^{\text {cde }} \\
(20.68)\end{array}$ & 64 & $\begin{array}{c}54.0^{\text {cdefg }} \\
(21.81)\end{array}$ & 64 & $\begin{array}{l}51.8^{\text {defghi }} \\
(20.78)\end{array}$ & 64 & $\begin{array}{l}47.5^{\text {ghij }} \\
(23.86)\end{array}$ \\
\hline Bentonite 228 (s) & 64 & $\begin{array}{c}62.3^{\mathrm{a}} \\
(15.94)\end{array}$ & 64 & $\begin{array}{c}62.2^{a} \\
(16.60)\end{array}$ & 64 & $\begin{array}{c}60.3 \\
(14.66)\end{array}$ & 64 & $\begin{array}{c}63.8^{\mathrm{a}} \\
(17.82)\end{array}$ \\
\hline Bentonite VIN 13 (s) & 64 & $\begin{array}{l}57.0^{\text {bcde }} \\
(16.85)\end{array}$ & 64 & $\begin{array}{c}56.1^{\text {bcdef }} \\
(17.16)\end{array}$ & 64 & $\begin{array}{c}56.2^{\text {abcde }} \\
(16.47)\end{array}$ & 64 & $\begin{array}{l}55.2^{\text {bcde }} \\
(17.15)\end{array}$ \\
\hline Small-scale centrifugation 228 (s) & 63 & $\begin{array}{l}54.3^{\text {efg }} \\
(19.76)\end{array}$ & 63 & $\begin{array}{l}53.5^{\text {defg }} \\
(20.48)\end{array}$ & 63 & $\begin{array}{c}51.5^{\text {defghi }} \\
(19.10)\end{array}$ & 64 & $\begin{array}{c}51.7^{\text {defgh }} \\
(21.96)\end{array}$ \\
\hline Small-scale centrifugation VIN 13 (s) & 64 & $\begin{array}{l}59.5^{\text {abcd }} \\
(15.70)\end{array}$ & 64 & $\begin{array}{c}59.6^{\mathrm{ab}} \\
(16.50)\end{array}$ & 64 & $\begin{array}{c}56.7^{\text {abcd }} \\
(17.24)\end{array}$ & 64 & $\begin{array}{l}59.1^{\mathrm{abc}} \\
(17.54)\end{array}$ \\
\hline Whisk 228 (s) & 64 & $\begin{array}{l}56.6^{\text {bcde }} \\
(14.73)\end{array}$ & 64 & $\begin{array}{l}59.5^{\mathrm{abc}} \\
(14.57)\end{array}$ & 64 & $\begin{array}{l}57.1^{\mathrm{abc}} \\
(17.05)\end{array}$ & 64 & $\begin{array}{l}58.4^{\mathrm{abc}} \\
(17.66)\end{array}$ \\
\hline Whisk VIN 13 (s) & 64 & $\begin{array}{c}61.3^{\mathrm{ab}} \\
(16.02)\end{array}$ & 64 & $\begin{array}{c}60.4^{\mathrm{ab}} \\
(20.48)\end{array}$ & 64 & $\begin{array}{c}51.5^{\mathrm{ab}} \\
(19.10)\end{array}$ & 64 & $\begin{array}{c}59.9^{\mathrm{ab}} \\
(18.79)\end{array}$ \\
\hline Whisk 228 (L) & 64 & $\begin{array}{l}54.4^{\mathrm{efg}} \\
(17.40)\end{array}$ & 64 & $\begin{array}{l}52.9^{\text {efgh }} \\
(18.25)\end{array}$ & 64 & $\begin{array}{c}55.5^{\text {abcdef }} \\
(18.67)\end{array}$ & 64 & $\begin{array}{c}49.1^{\text {efghi }} \\
(20.80)\end{array}$ \\
\hline Large-scale centrifugation 228 (s) & 63 & $\begin{array}{l}47.3^{\text {hijkl }} \\
(19.24)\end{array}$ & 63 & $\begin{array}{l}47.2^{\mathrm{ijk}} \\
(20.12)\end{array}$ & 63 & $\begin{array}{l}49.7^{\text {ghij }} \\
(19.35)\end{array}$ & 64 & $\begin{array}{l}42.8^{\mathrm{jkl}} \\
(22.47)\end{array}$ \\
\hline Large-scale centrifugation VIN 13 (s) & 64 & $\begin{array}{l}49.4^{\text {hij }} \\
(20.15)\end{array}$ & 64 & $\begin{array}{l}49.7^{\text {ghij }} \\
(21.41)\end{array}$ & 64 & $\begin{array}{l}50.9^{\text {fghij }} \\
(21.62)\end{array}$ & 64 & $\begin{array}{l}46.5^{\text {hij }} \\
(23.67)\end{array}$ \\
\hline Large-scale centrifugation 228 (L) & 64 & $\begin{array}{l}48.5^{\text {hijk }} \\
(18.79)\end{array}$ & 64 & $\begin{array}{l}49.4^{\text {ghij }} \\
(19.32)\end{array}$ & 64 & $\begin{array}{c}52.1^{\text {cdefgh }} \\
(19.39)\end{array}$ & 64 & $\begin{array}{l}47.2^{\text {ghij }} \\
(20.88)\end{array}$ \\
\hline No yeast lees 228 & 37 & $\begin{array}{l}50.5^{\text {fgh }} \\
(19.76)\end{array}$ & 37 & $\begin{array}{l}47.5^{\mathrm{hijk}} \\
(20.98)\end{array}$ & 37 & $\begin{array}{c}44.0^{\mathrm{k}} \\
(21.18)\end{array}$ & 38 & $\begin{array}{l}47.4^{\text {ghij }} \\
(26.37)\end{array}$ \\
\hline $1 \times$ Yeast lees 228 & 37 & $\begin{array}{l}46.7^{\text {hijkl }} \\
(21.41)\end{array}$ & 37 & $\begin{array}{l}51.1^{\text {fghi }} \\
(23.44)\end{array}$ & 37 & $\begin{array}{c}51.8^{\text {cdefgihi }} \\
(21.93)\end{array}$ & 38 & $\begin{array}{c}48.7^{\text {fghij }} \\
(5.52)\end{array}$ \\
\hline $1.5 \mathrm{x}$ Yeast lees 228 & 36 & $\begin{array}{l}50.3^{\text {fgh }} \\
(19.51)\end{array}$ & 36 & $\begin{array}{l}49.5^{\text {ghij }} \\
(21.65)\end{array}$ & 36 & $\begin{array}{l}51.4^{\mathrm{efghi}} \\
(23.91)\end{array}$ & 38 & $\begin{array}{c}46.3^{\text {hij }} \\
(24.62)\end{array}$ \\
\hline $2 x$ Yeast lees 228 & 38 & $\begin{array}{l}48.1^{\text {hijk }} \\
(21.45)\end{array}$ & 38 & $\begin{array}{l}47.7^{\text {hij }} \\
(21.43)\end{array}$ & 38 & $\begin{array}{l}47.0^{\text {hijk }} \\
(21.38)\end{array}$ & 38 & $\begin{array}{l}43.0^{\mathrm{ijk}} \\
(23.27)\end{array}$ \\
\hline No yeast lees VIN 13 & 37 & $\begin{array}{c}49.9^{g h} \\
(16.97)\end{array}$ & 37 & $\begin{array}{c}47.0^{\mathrm{ijk}} \\
(20.68)\end{array}$ & 37 & $\begin{array}{c}46.1^{\mathrm{jk}} \\
(21.46)\end{array}$ & 37 & $\begin{array}{c}45.4^{\mathrm{ijk}} \\
(21.71)\end{array}$ \\
\hline 1 x Yeast lees VIN 13 & 38 & $\begin{array}{l}45.2^{\mathrm{ijkl}} \\
(25.53)\end{array}$ & 38 & $\begin{array}{l}46.6^{\mathrm{ijk}} \\
(28.05)\end{array}$ & 38 & $\begin{array}{l}46.8^{\text {hijk }} \\
(27.06)\end{array}$ & 37 & $\begin{array}{l}39.3^{\mathrm{klm}} \\
(26.19)\end{array}$ \\
\hline $1.5 \mathrm{x}$ Yeast lees VIN 13 & 38 & $\begin{array}{l}50.8^{\text {fgh }} \\
(21.93)\end{array}$ & 38 & $\begin{array}{l}48.9^{\text {ghij }} \\
(22.39)\end{array}$ & 38 & $\begin{array}{l}47.7^{\text {hijk }} \\
(24.61)\end{array}$ & 38 & $\begin{array}{l}46.8^{\text {hij }} \\
(24.43)\end{array}$ \\
\hline $2 \times$ Yeast lees VIN 13 & 37 & $\begin{array}{c}42.6^{1} \\
(24.46)\end{array}$ & 37 & $\begin{array}{c}41.9^{\mathrm{k}} \\
(22.40)\end{array}$ & 37 & $\begin{array}{l}46.6^{\mathrm{ijk}} \\
(26.89)\end{array}$ & 36 & $\begin{array}{c}37.3^{\mathrm{lm}} \\
(24.84)\end{array}$ \\
\hline
\end{tabular}

SD, standard deviation; s, small-scale distillation; L, large-scale distillation; -P, no pectolytic enzyme; +P, with pectolytic enzyme; N, number of evaluations of samples; With large-scale distillation, only yeast strain 228 (commonly used in the industry) was used; Treatments with the same superscript do not differ significantly ( $\mathrm{p} \geq 0.05$ ); All values represent the average of replicate data from four seasons. 
TABLE 2

Unmatured pot-still brandy evaluation data (1997-2000 seasons).

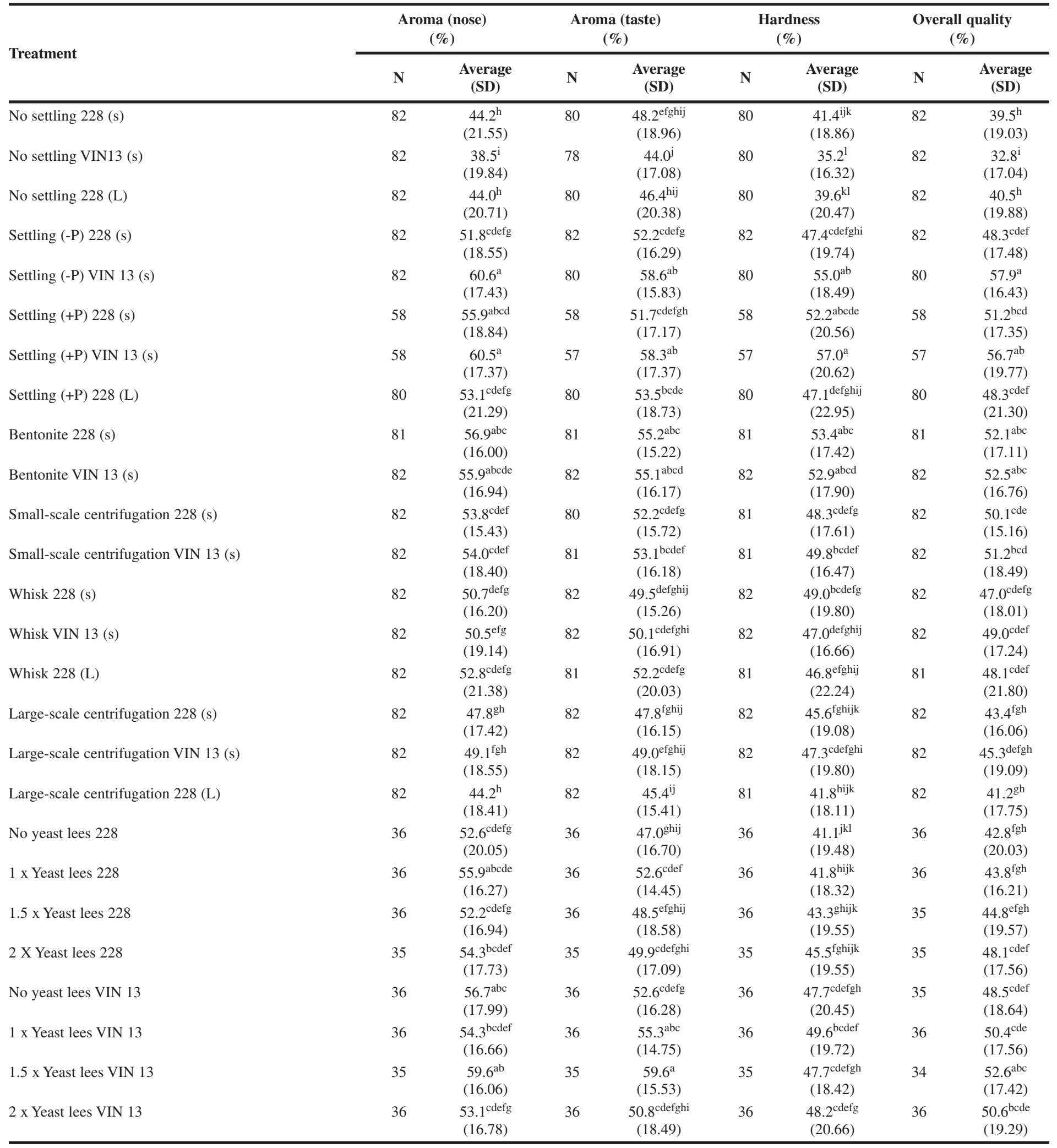

SD, standard deviation; s, small-scale distillation; L, large-scale distillation; -P, no pectolytic enzyme; $+\mathrm{P}$, with pectolytic enzyme; N, number of evaluations of samples; With large-scale distillation, only yeast strain 228 (commonly used in the industry) was used; Treatments with the same superscript do not differ significantly ( $\mathrm{p} \geq 0.05$ ); All values represent the average of replicate data from four seasons. 
TABLE 3

Total volatile component concentration $(\mathrm{mg} / \mathrm{L})$ of Chenin blanc brandy base wines and degree of turbidity of corresponding juices (1997-2000 seasons).

\begin{tabular}{|c|c|c|c|c|c|c|c|}
\hline Treatment & $\mathbf{N}$ & $\begin{array}{l}\text { Total } \\
\text { esters }\end{array}$ & $\begin{array}{l}\text { Total esters } \\
\quad(- \text { ethyl } \\
\text { acetate and } \\
\text { ethyl lactate) }\end{array}$ & $\begin{array}{l}\text { Total } \\
\text { acids }\end{array}$ & $\begin{array}{c}\text { Total } \\
\text { acids } \\
\text { (-acetic } \\
\text { acid) }\end{array}$ & $\begin{array}{c}\text { Total } \\
\text { higher } \\
\text { alcohols }\end{array}$ & $\begin{array}{l}\text { Degree of } \\
\text { turbidity* }\end{array}$ \\
\hline No settling 228 (s) & 6 & $\begin{array}{c}210.828^{\text {efg }} \\
(58.956)\end{array}$ & $\begin{array}{l}8.994^{\mathrm{hi}} \\
(3.235)\end{array}$ & $\begin{array}{l}433.073^{\mathrm{a}} \\
(104.269)\end{array}$ & $\begin{array}{c}25.912^{\text {efghijk }} \\
(13.908)\end{array}$ & $\begin{array}{c}375.429^{a} \\
(104.558)\end{array}$ & $\begin{array}{l}301.875^{\mathrm{a}} \\
(71.398)\end{array}$ \\
\hline No settling VIN13 (s) & 8 & $\begin{array}{c}161.860^{\mathrm{mn}} \\
(55.725)\end{array}$ & $\begin{array}{c}7.203^{\mathrm{k}} \\
(1.932)\end{array}$ & $\begin{array}{l}338.285^{\mathrm{bc}} \\
(136.627)\end{array}$ & $\begin{array}{c}23.382^{h i j k} \\
(13.950)\end{array}$ & $\begin{array}{l}367.838^{\mathrm{a}} \\
(81.393)\end{array}$ & $\begin{array}{l}301.875^{\mathrm{a}} \\
(71.398)\end{array}$ \\
\hline No settling 228 (L) & 8 & $\begin{array}{c}137.581^{\mathrm{op}} \\
(29.449)\end{array}$ & $\begin{array}{l}9.125^{\text {ghi }} \\
(2.823)\end{array}$ & $\begin{array}{l}231.891^{\mathrm{i}} \\
(39.306)\end{array}$ & $\begin{array}{c}22.951^{\mathrm{ijk}} \\
(7.659)\end{array}$ & $\begin{array}{l}358.388^{\mathrm{a}} \\
(85.183)\end{array}$ & $\begin{array}{l}301.875^{\mathrm{a}} \\
(71.398)\end{array}$ \\
\hline Settling (-P) 228 (s) & 6 & $\begin{array}{c}196.774^{\text {ghij }} \\
(40.513)\end{array}$ & $\begin{array}{l}12.499^{\mathrm{cd}} \\
(3.722)\end{array}$ & $\begin{array}{l}220.619^{\mathrm{ij}} \\
(104.051)\end{array}$ & $\begin{array}{c}33.092^{\mathrm{ab}} \\
(7.701)\end{array}$ & $\begin{array}{c}237.658^{\text {fgh }} \\
(44.690)\end{array}$ & $\begin{array}{l}39.938^{c} \\
(24.759)\end{array}$ \\
\hline Settling (-P) VIN 13 (s) & 8 & $\begin{array}{c}195.513^{\text {hij }} \\
(47.442)\end{array}$ & $\begin{array}{l}15.033^{\mathrm{a}} \\
(2.294)\end{array}$ & $\begin{array}{l}284.014^{\mathrm{efg}} \\
(162.181)\end{array}$ & $\begin{array}{c}33.813^{\mathrm{ab}} \\
(3.004)\end{array}$ & $\begin{array}{l}270.174^{\mathrm{e}} \\
(48.659)\end{array}$ & $\begin{array}{l}39.938^{c} \\
(24.759)\end{array}$ \\
\hline Settling (+P) $228(\mathrm{~s})$ & 6 & $\begin{array}{l}237.048^{c} \\
(22.833)\end{array}$ & $\begin{array}{l}12.106^{\text {cdef }} \\
(3.229)\end{array}$ & $\begin{array}{c}294.594^{\mathrm{de}} \\
(55.893)\end{array}$ & $\begin{array}{c}29.747^{\text {bcdef }} \\
(5.659)\end{array}$ & $\begin{array}{c}240.522^{f g} \\
(42.445)\end{array}$ & $\begin{array}{l}48.317^{\mathrm{c}} \\
(21.103)\end{array}$ \\
\hline Settling (+P) VIN 13 (s) & 6 & $\begin{array}{c}219.207^{\mathrm{de}} \\
(13.339)\end{array}$ & $\begin{array}{l}13.615^{\mathrm{b}} \\
(2.526)\end{array}$ & $\begin{array}{l}299.561^{\mathrm{de}} \\
(154.484)\end{array}$ & $\begin{array}{c}26.808^{\text {defghij }} \\
(4.392)\end{array}$ & $\begin{array}{l}265.582^{\mathrm{e}} \\
(57.760)\end{array}$ & $\begin{array}{l}48.317^{\mathrm{c}} \\
(21.103)\end{array}$ \\
\hline Settling (+P) $228(\mathrm{~L})$ & 6 & $\begin{array}{c}168.576^{\mathrm{lm}} \\
(39.884)\end{array}$ & $\begin{array}{c}14.308^{a b} \\
(4.287)\end{array}$ & $\begin{array}{l}158.128^{\mathrm{k}} \\
(49.272)\end{array}$ & $\begin{array}{c}30.527^{\text {abcde }} \\
(4.446)\end{array}$ & $\begin{array}{c}232.754^{\text {fghi }} \\
(43.631)\end{array}$ & $\begin{array}{l}36.988^{c} \\
(21.916)\end{array}$ \\
\hline Bentonite 228 (s) & 8 & $\begin{array}{c}285.758^{\mathrm{b}} \\
(68.719)\end{array}$ & $\begin{array}{l}12.612^{c} \\
(2.656)\end{array}$ & $\begin{array}{l}338.113^{b c} \\
(154.111)\end{array}$ & $\begin{array}{l}35.148^{\mathrm{a}} \\
(10.217)\end{array}$ & $\begin{array}{l}219.491^{\mathrm{hij}} \\
(27.849)\end{array}$ & $\begin{array}{l}86.500^{\mathrm{bc}} \\
(75.783)\end{array}$ \\
\hline Bentonite VIN 13 (s) & 8 & $\begin{array}{c}192.911^{\mathrm{hijk}} \\
(51.442)\end{array}$ & $\begin{array}{l}13.597^{b} \\
(3.637)\end{array}$ & $\begin{array}{l}286.029^{\text {def }} \\
(185.803)\end{array}$ & $\begin{array}{c}31.524^{\mathrm{abc}} \\
(4.815)\end{array}$ & $\begin{array}{c}237.470^{\text {fgh }} \\
(57.413)\end{array}$ & $\begin{array}{l}86.500^{\mathrm{bc}} \\
(75.783)\end{array}$ \\
\hline Small-scale centrifugation 228 (s) & 7 & $\begin{array}{c}202.419^{\text {fgh }} \\
(52.680)\end{array}$ & $\begin{array}{c}11.730^{\mathrm{def}} \\
(3.424)\end{array}$ & $\begin{array}{c}303.691^{\text {cde }} \\
(75.714)\end{array}$ & $\begin{array}{c}30.619^{\mathrm{abcd}} \\
(7.497)\end{array}$ & $\begin{array}{c}297.865^{\mathrm{cd}} \\
(99.798)\end{array}$ & $\begin{array}{l}81.750^{\mathrm{bc}} \\
(21.515)\end{array}$ \\
\hline Small-scale centrifugation VIN 13 (s) & 8 & $\begin{array}{c}183.047^{\mathrm{jk}} \\
(67.095)\end{array}$ & $\begin{array}{l}12.683^{c} \\
(2.508)\end{array}$ & $\begin{array}{l}306.743^{\text {cde }} \\
(169.996)\end{array}$ & $\begin{array}{c}27.956^{\mathrm{cdefgh}} \\
(4.671)\end{array}$ & $\begin{array}{c}295.786^{\mathrm{cd}} \\
(54.180)\end{array}$ & $\begin{array}{l}81.750^{b c} \\
(21.515)\end{array}$ \\
\hline Whisk 228 (s) & 8 & $\begin{array}{c}187.327^{\mathrm{ijk}} \\
(48.464)\end{array}$ & $\begin{array}{l}11.317^{\mathrm{f}} \\
(3.644)\end{array}$ & $\begin{array}{l}220.682^{\mathrm{ij}} \\
(72.375)\end{array}$ & $\begin{array}{c}26.967^{\text {cdefghi }} \\
(5.144)\end{array}$ & $\begin{array}{l}282.226^{\mathrm{de}} \\
(122.248)\end{array}$ & $\begin{array}{l}127.300^{\mathrm{bc}} \\
(118.729)\end{array}$ \\
\hline Whisk VIN 13 (s) & 7 & $\begin{array}{c}150.774^{\text {no }} \\
(60.099)\end{array}$ & $\begin{array}{l}11.580^{\mathrm{ef}} \\
(4.224)\end{array}$ & $\begin{array}{l}218.592^{\mathrm{ij}} \\
(143.689)\end{array}$ & $\begin{array}{c}24.840^{\text {ghijk }} \\
(6.008)\end{array}$ & $\begin{array}{c}301.509^{c} \\
(100.072)\end{array}$ & $\begin{array}{l}127.300^{\mathrm{bc}} \\
(118.729)\end{array}$ \\
\hline Whisk 228 (L) & 8 & $\begin{array}{c}161.406^{\mathrm{mn}} \\
(39.727)\end{array}$ & $\begin{array}{c}12.315^{\mathrm{cde}} \\
(4.926)\end{array}$ & $\begin{array}{l}185.404^{\mathrm{jk}} \\
(82.278)\end{array}$ & $\begin{array}{c}25.507^{\text {fghijk }} \\
(9.378)\end{array}$ & $\begin{array}{l}265.505^{\mathrm{e}} \\
(61.698)\end{array}$ & $\begin{array}{l}128.500^{b c} \\
(117.356)\end{array}$ \\
\hline Large-scale centrifugation 228 (s) & 7 & $\begin{array}{c}196.642^{\text {ghij }} \\
(73.899)\end{array}$ & $\begin{array}{l}11.256^{\mathrm{f}} \\
(4.245)\end{array}$ & $\begin{array}{l}243.055^{\mathrm{hi}} \\
(97.024)\end{array}$ & $\begin{array}{c}27.033^{\text {cdefghi }} \\
(6.097)\end{array}$ & $\begin{array}{c}289.306^{\mathrm{cd}} \\
(86.281)\end{array}$ & $\begin{array}{c}184.125^{\mathrm{b}} \\
(101.091)\end{array}$ \\
\hline Large-scale centrifugation VIN 13 (s) & 8 & $\begin{array}{l}180.608^{\mathrm{kl}} \\
(74.090)\end{array}$ & $\begin{array}{l}9.962^{\mathrm{g}} \\
(3.870)\end{array}$ & $\begin{array}{c}344.896^{\mathrm{b}} \\
(156.307)\end{array}$ & $\begin{array}{l}29.143^{\text {bcdefg }} \\
(12.611)\end{array}$ & $\begin{array}{l}328.707^{b} \\
(76.440)\end{array}$ & $\begin{array}{l}184.125^{\mathrm{b}} \\
(101.091)\end{array}$ \\
\hline Large-scale centrifugation 228 (L) & 8 & $\begin{array}{l}131.595^{p} \\
(65.745)\end{array}$ & $\begin{array}{l}9.827^{\mathrm{gh}} \\
(3.305)\end{array}$ & $\begin{array}{l}164.020^{\mathrm{k}} \\
(79.382)\end{array}$ & $\begin{array}{c}22.221^{\mathrm{jk}} \\
(3.533)\end{array}$ & $\begin{array}{l}244.717^{f} \\
(41.798)\end{array}$ & $\begin{array}{l}184.125^{\mathrm{b}} \\
(101.091)\end{array}$ \\
\hline No yeast lees 228 & 4 & $\begin{array}{c}303.742^{\mathrm{a}} \\
(112.556)\end{array}$ & $\begin{array}{l}9.014^{\mathrm{hi}} \\
(0.458)\end{array}$ & $\begin{array}{c}248.324^{\text {fghi }} \\
(133.134)\end{array}$ & $\begin{array}{c}22.142^{\mathrm{jk}} \\
(1.950)\end{array}$ & $\begin{array}{l}212.614^{\mathrm{j}} \\
(42.851)\end{array}$ & - \\
\hline 1 x Yeast lees 228 & 4 & $\begin{array}{l}306.596^{\mathrm{a}} \\
(120.791)\end{array}$ & $\begin{array}{l}7.849^{\mathrm{jk}} \\
(0.504)\end{array}$ & $\begin{array}{c}276.808^{\mathrm{efgh}} \\
(132.379)\end{array}$ & $\begin{array}{c}23.791^{\text {hijk }} \\
(8.160)\end{array}$ & $\begin{array}{l}213.993^{j} \\
(39.523)\end{array}$ & - \\
\hline $1.5 \mathrm{x}$ Yeast lees 228 & 4 & $\begin{array}{l}296.537^{a b} \\
(106.169)\end{array}$ & $\begin{array}{l}8.290^{\mathrm{ij}} \\
(0.959)\end{array}$ & $\begin{array}{c}309.023^{\text {bcde }} \\
(182.164)\end{array}$ & $\begin{array}{c}23.420^{\text {hijk }} \\
(4.901)\end{array}$ & $\begin{array}{l}214.386^{\mathrm{ij}} \\
(39.094)\end{array}$ & - \\
\hline 2 x Yeast lees 228 & 4 & $\begin{array}{l}293.098^{a b} \\
(106.178)\end{array}$ & $\begin{array}{l}8.295^{\mathrm{ij}} \\
(0.957)\end{array}$ & $\begin{array}{l}323.157^{\text {bcd }} \\
(188.149)\end{array}$ & $\begin{array}{c}22.809^{\mathrm{ijk}} \\
(2.013)\end{array}$ & $\begin{array}{l}209.315^{j} \\
(40.379)\end{array}$ & - \\
\hline No yeast lees VIN 13 & 4 & $\begin{array}{c}198.118^{\mathrm{ghi}} \\
(7.126)\end{array}$ & $\begin{array}{l}9.654^{\text {gh }} \\
(0.612)\end{array}$ & $\begin{array}{l}191.510^{\mathrm{jk}} \\
(140.328)\end{array}$ & $\begin{array}{l}21.647^{\mathrm{k}} \\
(0.882)\end{array}$ & $\begin{array}{c}219.680^{\mathrm{hij}} \\
(46.693)\end{array}$ & - \\
\hline $1 \times$ Yeast lees VIN 13 & 4 & $\begin{array}{c}227.705^{\mathrm{cd}} \\
(42.834)\end{array}$ & $\begin{array}{l}8.445^{\mathrm{ij}} \\
(0.361)\end{array}$ & $\begin{array}{l}241.434^{\mathrm{hi}} \\
(197.746)\end{array}$ & $\begin{array}{c}23.254^{\mathrm{ijk}} \\
(0.641)\end{array}$ & $\begin{array}{c}223.530^{\text {ghij }} \\
(47.575)\end{array}$ & - \\
\hline 1.5 x Yeast lees VIN 13 & 4 & $\begin{array}{c}216.080^{\text {def }} \\
(37.471)\end{array}$ & $\begin{array}{c}8.777^{\mathrm{i}} \\
(0.680)\end{array}$ & $\begin{array}{l}245.970^{\mathrm{ghi}} \\
(200.340)\end{array}$ & $\begin{array}{c}22.215^{\mathrm{jk}} \\
(1.721)\end{array}$ & $\begin{array}{c}221.602^{\mathrm{hij}} \\
(47.279)\end{array}$ & - \\
\hline $2 \times$ Yeast lees VIN 13 & 3 & $\begin{array}{c}203.510^{\mathrm{fgh}} \\
(25.870)\end{array}$ & $\begin{array}{l}8.300^{\mathrm{ij}} \\
(0.845)\end{array}$ & $\begin{array}{l}192.189^{\mathrm{jk}} \\
(196.677)\end{array}$ & $\begin{array}{c}24.801^{\text {ghijk }} \\
(3.810)\end{array}$ & $\begin{array}{l}208.924^{\mathrm{j}} \\
(35.956)\end{array}$ & - \\
\hline
\end{tabular}

s, small-scale distillation; L, large-scale distillation; -P, no pectolytic enzyme; $+\mathrm{P}$, with pectolytic enzyme; With large-scale distillation only yeast strain 228 (commonly used in the industry) was used; Treatments with the same superscript do not differ significantly ( $\mathrm{p} \geq 0.05)$; $\mathrm{N}$, number of replicate samples analysed; All values in brackets represent the standard deviation; *Degree of turbidity of must after treatment (Klett-units); All values represent the average of replicate data from four seasons. 


\section{TABLE 4}

Total volatile component concentration $(\mathrm{mg} / \mathrm{L})$ of Chenin blanc unmatured pot-still brandies and degree of turbidity of corresponding juices (1997-2000 seasons).

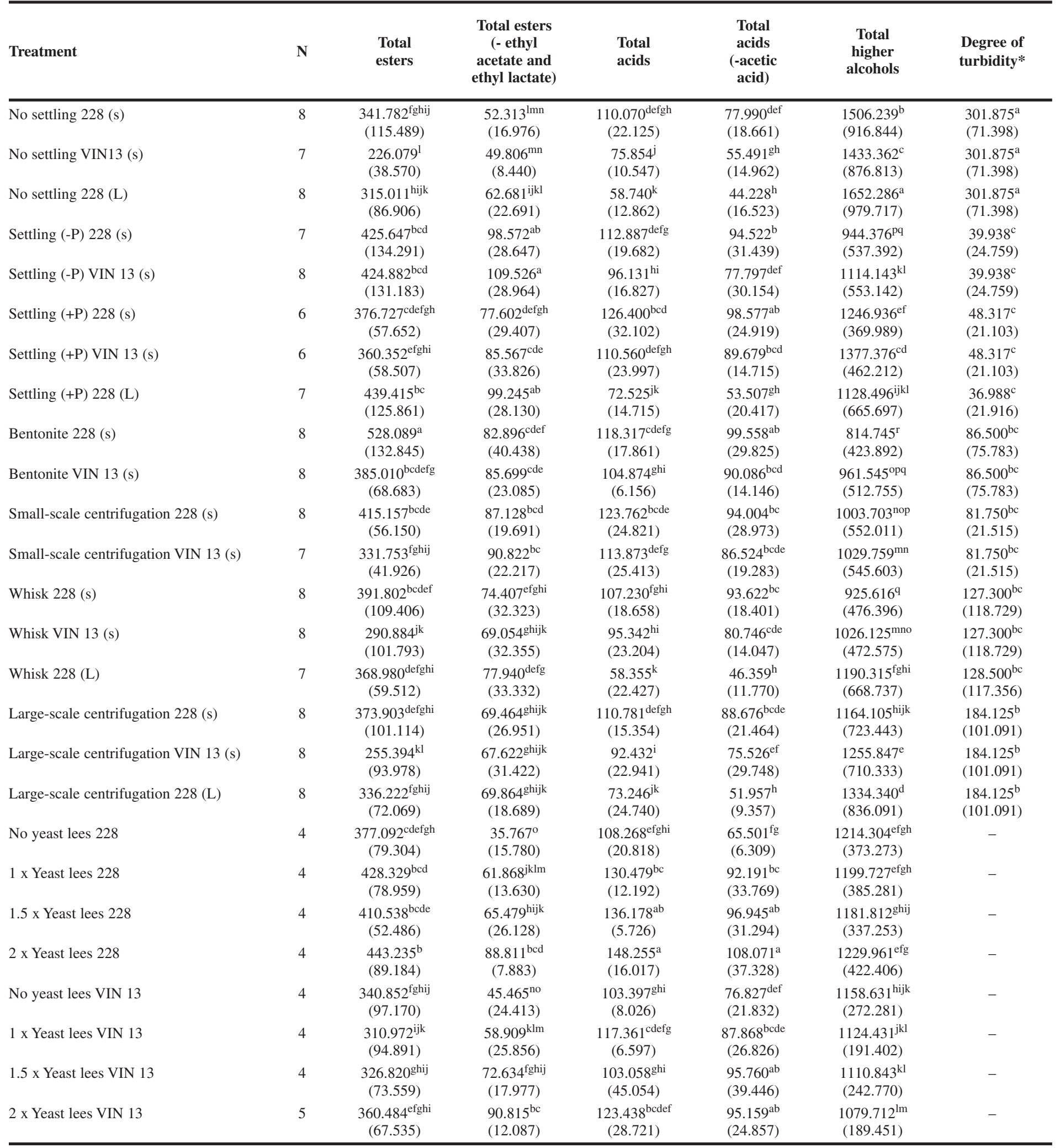

s, small-scale distillation; L, large-scale distillation; -P, no pectolytic enzyme; +P, with pectolytic enzyme; With large-scale distillation only yeast strain 228 (commonly used in the industry) was used; Treatments with the same superscript do not differ significantly ( $\mathrm{p} \geq 0.05$ ); N, number of replicate samples analysed; All values in brackets represent the standard deviation; *Degree of turbidity of juice after treatment (Klett-units); All values represent the average of replicate data from four seasons. 
A

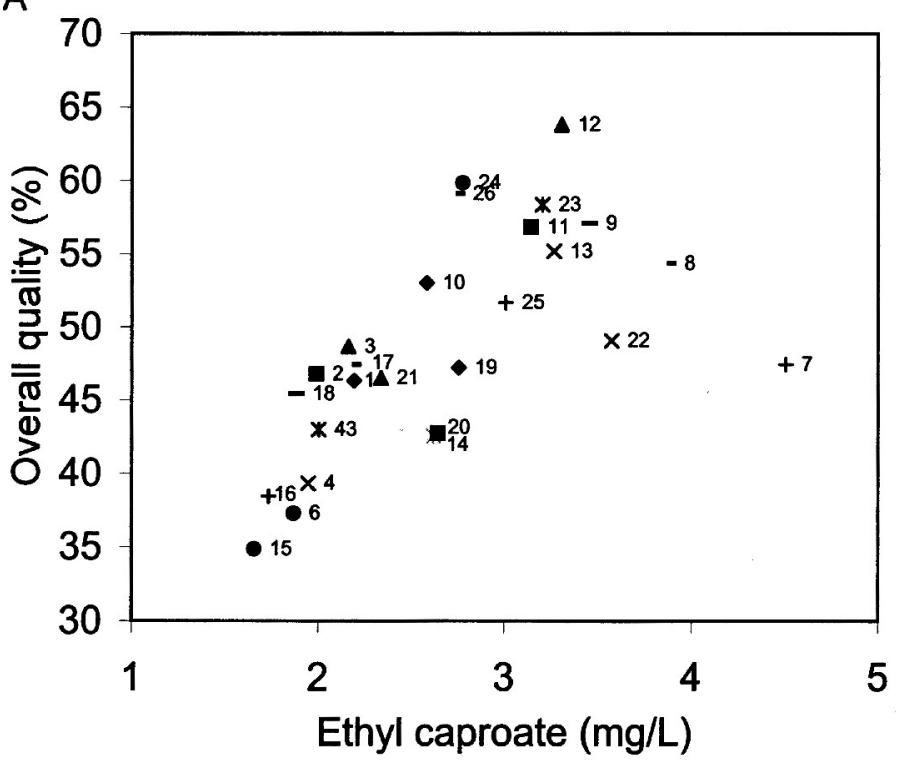

B

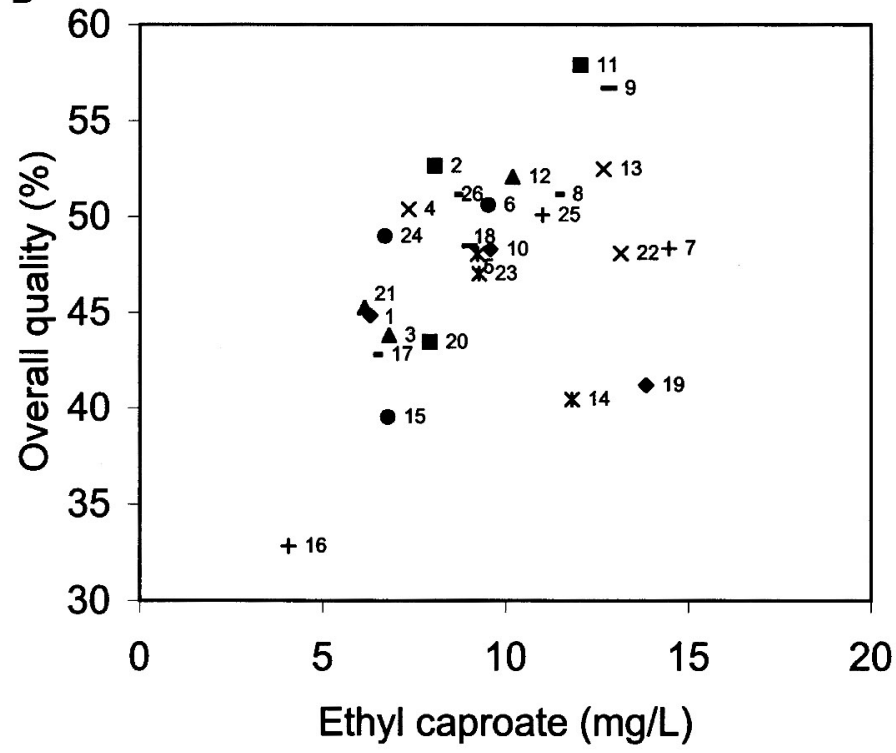

FIGURE 1

Effect of juice clarification method on ethyl caproate concentration and overall brandy base wine (part A) and unmatured pot-still brandy (part B) quality. $(\mathrm{A}), \mathrm{r}=0.63$ and $\mathrm{p}=0.0006$. (B), $\mathrm{r}=0.47$ and $\mathrm{p}=0.0161$. Each symbol represents the average data of four seasons. Treatment: 1 , 1.5x yeast lees $228 ; 2,1.5 \mathrm{x}$ yeast lees VIN $13 ; 3$, 1x yeast lees 228; 4, 1x yeast lees VIN 13; 5, 2x yeast lees 228; 6, 2x yeast lees VIN 13; 7, settling (+P) 228 (L); 8, settling (+P) 228 (s); 9 , settling (+P) VIN 13 (s); 10 , settling (-P) 228 (s); 11, settling (-P) VIN 13 (s); 12, bentonite 228 (s); 13, bentonite VIN 13 (s); 14, no settling 228 (L); 15 , no settling 228 (s); 16 , no settling VIN 13 (s); 17, no yeast lees 228; 18, no yeast lees VIN 13; 19, large-scale centrifugation 228 (L); 20, large-scale centrifugation 228 (s); 21 , large-scale centrifugation VIN 13 (s); 22, whisk 228 (L); 23, whisk 228 (s); 24, whisk VIN 13 (s); 25, small-scale centrifugation 228 (s); 26, small-scale centrifugation VIN 13 (s). s, Small-scale distillation; $\mathrm{L}$, large-scale distillation; $-\mathrm{P}$, no pectolytic enzyme and $+\mathrm{P}$, with pectolytic enzyme.

Total higher alcohol concentrations in wine for all the treatments fell within literature-reported ranges $(<100$ to $>500 \mathrm{mg} / \mathrm{L})$ and were mostly lower than $300 \mathrm{mg} / \mathrm{L}$, except for no settling and largescale centrifugation. This explains why these two types of treatments delivered lower quality products. It is known that higher alcohol concentrations of less than $300 \mathrm{mg} / \mathrm{L}$ deliver a positive contribution to the desired complexity of wine, and that concentrations of more than $400 \mathrm{mg} / \mathrm{L}$ have a negative effect on quality (Lambrechts \& Pretorius, 2000). In comparison to the corresponding brandy base wine, higher levels of higher alcohols were present in unmatured pot-still brandy (see Tables 3 and 4). Isoamyl alcohol is one of the most abundant higher alcohols in brandy base wine and unmatured pot-still brandy, constituting about $57 \%$ in wine and about $79 \%$ in unmatured pot-still brandy of the total fusel alcohol fraction, which compares well with reported values of 40 to $70 \%$ for different beverages (Lambrechts \& Pretorius, 2000).

Acetic acid is clearly the most prolific volatile acid of undistilled and distilled beverages. In this study, acetic acid made up 81 to $94 \%$ of the total volatile acid concentration in wine, and 7 to $40 \%$ in unmatured pot-still brandy, in comparison with reported values of more than $90 \%$ for wine (Lambrechts \& Pretorius, 2000), $50 \%$ in cognac and $75 \%$ in South African brandy (Nykänen et al., 1968). Although the highest acetic acid concentrations (300 to $408 \mathrm{mg} / \mathrm{L}$ for wine and $>43 \mathrm{mg} / \mathrm{L}$ for unmatured pot-still brandy) could be associated with the lowest quality in this study, they compared well with reported aroma threshold val- ues of between 100 and $1100 \mathrm{mg} / \mathrm{L}$ (depending on the style of wine), and a legally permitted volatile acid (expressed as acetic acid) limit of $700 \mathrm{mg} / \mathrm{L}$ for base wines for brandy, cognac and armagnac; however, even within these parameters, concentrations above $300 \mathrm{mg} / \mathrm{L}$ can affect quality. They were still lower than the general volatile acid content of 500 to $1000 \mathrm{mg} / \mathrm{L}$ for wine and $200 \mathrm{mg} / \mathrm{L}$ for cognac as reported by Lambrechts \& Pretorius (2000). The concentrations of other volatile acids in brandy base wine and unmatured pot-still brandy in this study (data not shown) compared well to reported range values (Lambrechts \& Pretorius, 2000).

As reported in literature (Nykänen et al., 1968; Crowell \& Guymon, 1969; Guymon \& Crowell, 1969; Shinohara, 1985), after acetic acid, it is the ethyl esters of fatty acids with an even number of carbon atoms, especially hexanoic $\left(\mathrm{C}_{6}\right)$, octanoic $\left(\mathrm{C}_{8}\right)$, decanoic $\left(\mathrm{C}_{10}\right)$, lauric $\left(\mathrm{C}_{12}\right)$, myristic $\left(\mathrm{C}_{14}\right)$ and palmitic acid $\left(\mathrm{C}_{16}\right)$ that form the main and/or most characteristic (fatty) acid components of alcoholic drinks like wine and spirits/brandy. Similar to the findings of Shinohara (1985), n-caprylic acid was also present in higher quantities in wine than n-caproic acid and n-capric acid (see Table 3). Treatments that led to n-caproic acid, n-caprylic acid and n-capric acid concentrations close to or above the reported threshold values of between 6 and $10 \mathrm{mg} / \mathrm{L}$, respectively (Shinohara, 1985), also delivered higher quality products in this study, with no settling and large-scale centrifugation delivering the lowest levels and lowest quality. 
TABLE 5

Long-chain fatty acid concentration (mg/L) and degree of turbidity of unmatured pot-still brandies (1997-2000 seasons).

\begin{tabular}{|c|c|c|c|c|c|c|}
\hline \multirow{2}{*}{ Treatment } & \multicolumn{5}{|c|}{ Long-chain fatty acid concentration (mg/l) } & \multirow{2}{*}{$\begin{array}{l}\text { Degree of } \\
\text { turbidity* }\end{array}$} \\
\hline & $\mathrm{C}_{12}$ & $\mathrm{C}_{14}$ & $\mathrm{C}_{16}$ & $\mathrm{C}_{18}$ & Total & \\
\hline No settling 228 (s) & $\begin{array}{c}21.639^{\mathrm{ab}} \\
(5.602)\end{array}$ & $\begin{array}{l}2.907^{\mathrm{e}} \\
(1.085)\end{array}$ & $\begin{array}{l}9.037^{\mathrm{ef}} \\
(2.003)\end{array}$ & $\begin{array}{l}0.595^{\mathrm{b}} \\
(0.007)\end{array}$ & $\begin{array}{l}34.178^{b} \\
(6.456)\end{array}$ & $\begin{array}{l}301.875^{\mathrm{a}} \\
(71.398)\end{array}$ \\
\hline No settling VIN13 (s) & $\begin{array}{c}20.276^{\mathrm{ab}} \\
(5.246)\end{array}$ & $\begin{array}{l}5.951^{\text {cde }} \\
(5.958)\end{array}$ & $\begin{array}{c}10.373^{\mathrm{def}} \\
(2.565)\end{array}$ & $\begin{array}{c}0.520^{b} \\
(0.028)\end{array}$ & $\begin{array}{l}37.120^{\mathrm{b}} \\
(9.280)\end{array}$ & $\begin{array}{l}301.875^{\mathrm{a}} \\
(71.398)\end{array}$ \\
\hline No settling 228 (L) & $\begin{array}{l}13.887^{b} \\
(7.968)\end{array}$ & $\begin{array}{c}5.989 \mathrm{cde} \\
(6.937)\end{array}$ & $\begin{array}{c}11.926^{\text {cdef }} \\
(5.797)\end{array}$ & $\begin{array}{l}1.100^{\mathrm{ab}} \\
(0.283)\end{array}$ & $\begin{array}{l}32.902^{b} \\
(13.492)\end{array}$ & $\begin{array}{l}301.875^{a} \\
(71.398)\end{array}$ \\
\hline Settling (-P) 228 (s) & $\begin{array}{l}30.144^{a b} \\
(18.171)\end{array}$ & $\begin{array}{c}4.820^{\text {cde }} \\
(3.358)\end{array}$ & $\begin{array}{c}11.075^{\mathrm{def}} \\
(3.039)\end{array}$ & $\begin{array}{l}0.800^{\mathrm{ab}} \\
(0.141)\end{array}$ & $\begin{array}{l}46.839^{b} \\
(20.492)\end{array}$ & $\begin{array}{c}39.938^{c} \\
(24.759)\end{array}$ \\
\hline Settling (-P) VIN 13 (s) & $\begin{array}{c}37.010^{\mathrm{a}} \\
(17.677)\end{array}$ & $\begin{array}{c}2.573^{\mathrm{e}} \\
(0.147)\end{array}$ & $\begin{array}{c}11.702^{\text {cdef }} \\
(2.745)\end{array}$ & $\begin{array}{c}1.650^{\mathrm{a}} \\
(1.485)\end{array}$ & $\begin{array}{l}52.935^{\mathrm{ab}} \\
(20.452)\end{array}$ & $\begin{array}{c}39.938^{c} \\
(24.759)\end{array}$ \\
\hline Settling (+P) $228(\mathrm{~s})$ & $\begin{array}{l}23.575^{a b} \\
(12.538)\end{array}$ & $\begin{array}{l}2.581^{\mathrm{e}} \\
(1.608)\end{array}$ & $\begin{array}{c}10.460^{\mathrm{def}} \\
(3.066)\end{array}$ & $0.900^{\mathrm{ab}}$ & $\begin{array}{l}37.516^{\mathrm{b}} \\
(16.533)\end{array}$ & $\begin{array}{l}48.317^{\mathrm{c}} \\
(21.103)\end{array}$ \\
\hline Settling (+P) VIN 13 (s) & $\begin{array}{l}21.505^{\mathrm{ab}} \\
(11.431)\end{array}$ & $\begin{array}{l}5.562^{\text {cde }} \\
(4.958)\end{array}$ & $\begin{array}{c}11.860^{\text {cdef }} \\
(3.525)\end{array}$ & $0.800^{\mathrm{ab}}$ & $\begin{array}{l}39.727^{b} \\
(13.292)\end{array}$ & $\begin{array}{l}48.317^{c} \\
(21.103)\end{array}$ \\
\hline Settling (+P) $228(\mathrm{~L})$ & $\begin{array}{l}18.961^{a b} \\
(12.653)\end{array}$ & $\begin{array}{l}9.745^{\mathrm{bcd}} \\
(6.411)\end{array}$ & $\begin{array}{l}19.967^{\mathrm{b}} \\
(5.228)\end{array}$ & $\begin{array}{l}1.305^{\mathrm{ab}} \\
(0.007)\end{array}$ & $\begin{array}{l}49.978^{b} \\
(12.460)\end{array}$ & $\begin{array}{l}36.988^{c} \\
(21.916)\end{array}$ \\
\hline Bentonite 228 (s) & $\begin{array}{l}23.630^{\mathrm{ab}} \\
(14.109)\end{array}$ & $\begin{array}{c}2.234^{\mathrm{e}} \\
(0.441)\end{array}$ & $\begin{array}{l}9.701^{\mathrm{def}} \\
(1.573)\end{array}$ & $\begin{array}{l}0.565^{\mathrm{b}} \\
(0.092)\end{array}$ & $\begin{array}{c}36.130^{\mathrm{b}} \\
(15.961)\end{array}$ & $\begin{array}{l}86.500^{\mathrm{bc}} \\
(75.783)\end{array}$ \\
\hline Bentonite VIN 13 (s) & $\begin{array}{c}26.466^{\mathrm{ab}} \\
(7.338)\end{array}$ & $\begin{array}{c}2.139^{\mathrm{e}} \\
(0.292)\end{array}$ & $\begin{array}{l}9.413^{\mathrm{def}} \\
(2.010)\end{array}$ & $\begin{array}{l}0.575^{b} \\
(0.106)\end{array}$ & $\begin{array}{l}38.593^{b} \\
(9.318)\end{array}$ & $\begin{array}{l}86.500^{\mathrm{bc}} \\
(75.783)\end{array}$ \\
\hline Small-scale centrifugation 228 (s) & $\begin{array}{l}25.188^{a b} \\
(18.105)\end{array}$ & $\begin{array}{c}4.982^{\text {cde }} \\
(3.815)\end{array}$ & $\begin{array}{l}9.950^{\mathrm{def}} \\
(2.110)\end{array}$ & $\begin{array}{c}0.550^{\mathrm{b}} \\
(0.071)\end{array}$ & $\begin{array}{l}40.670^{b} \\
(18.081)\end{array}$ & $\begin{array}{l}81.750^{\mathrm{bc}} \\
(21.515)\end{array}$ \\
\hline Small-scale centrifugation VIN 13 (s) & $\begin{array}{l}33.800^{\mathrm{ab}} \\
(18.629)\end{array}$ & $\begin{array}{c}2.761^{\mathrm{e}} \\
(0.816)\end{array}$ & $\begin{array}{l}9.319^{\mathrm{def}} \\
(2.305)\end{array}$ & $\begin{array}{l}0.700^{\mathrm{ab}} \\
(0.273)\end{array}$ & $\begin{array}{l}46.580^{b} \\
(22.126)\end{array}$ & $\begin{array}{l}81.750^{\mathrm{bc}} \\
(21.515)\end{array}$ \\
\hline Whisk 228 (s) & $\begin{array}{l}21.691^{a b} \\
(19.558)\end{array}$ & $\begin{array}{c}3.059^{\mathrm{e}} \\
(1.997)\end{array}$ & $\begin{array}{c}7.822^{\mathrm{f}} \\
(5.329)\end{array}$ & $\begin{array}{l}0.420^{\mathrm{b}} \\
(0.552)\end{array}$ & $\begin{array}{l}32.992^{b} \\
(26.034)\end{array}$ & $\begin{array}{l}127.300^{\mathrm{bc}} \\
(118.729)\end{array}$ \\
\hline Whisk VIN 13 (s) & $\begin{array}{l}25.847^{a b} \\
(12.963)\end{array}$ & $\begin{array}{l}2.944^{\mathrm{e}} \\
(0.622)\end{array}$ & $\begin{array}{c}11.975^{\text {cdef }} \\
(1.197)\end{array}$ & $\begin{array}{l}0.590^{\mathrm{b}} \\
(0.127)\end{array}$ & $\begin{array}{l}41.356^{\mathrm{b}} \\
(12.985)\end{array}$ & $\begin{array}{l}127.300^{\mathrm{bc}} \\
(118.729)\end{array}$ \\
\hline Whisk 228 (L) & $\begin{array}{l}15.370^{\mathrm{ab}} \\
(14.903)\end{array}$ & $\begin{array}{l}6.030^{\text {cde }} \\
(6.988)\end{array}$ & $\begin{array}{c}13.182^{\text {cdef }} \\
(7.667)\end{array}$ & $\begin{array}{l}1.190^{\mathrm{ab}} \\
(0.552)\end{array}$ & $\begin{array}{l}35.772^{b} \\
(23.338)\end{array}$ & $\begin{array}{l}128.500^{\mathrm{bc}} \\
(117.356)\end{array}$ \\
\hline Large-scale centrifugation 228 (s) & $\begin{array}{l}21.748^{a b} \\
(18.356)\end{array}$ & $\begin{array}{l}3.408^{\mathrm{de}} \\
(1.359)\end{array}$ & $\begin{array}{l}9.983^{\mathrm{def}} \\
(2.513)\end{array}$ & $\begin{array}{c}0.480^{\mathrm{b}} \\
(0.113)\end{array}$ & $\begin{array}{l}35.619^{b} \\
(19.009)\end{array}$ & $\begin{array}{c}184.125^{\mathrm{b}} \\
(101.091)\end{array}$ \\
\hline Large-scale centrifugation VIN 13 (s) & $\begin{array}{l}29.240^{\mathrm{ab}} \\
(19.612)\end{array}$ & $\begin{array}{l}6.245^{\mathrm{cde}} \\
(3.101)\end{array}$ & $\begin{array}{c}11.250^{\mathrm{def}} \\
(1.350)\end{array}$ & $\begin{array}{l}0.610^{\mathrm{b}} \\
(0.297)\end{array}$ & $\begin{array}{l}47.345^{b} \\
(17.991)\end{array}$ & $\begin{array}{c}184.125^{\mathrm{b}} \\
(101.091)\end{array}$ \\
\hline Large-scale centrifugation 228 (L) & $\begin{array}{l}19.366^{\mathrm{ab}} \\
(12.057)\end{array}$ & $\begin{array}{l}6.464^{\text {cde }} \\
(7.360)\end{array}$ & $\begin{array}{c}17.375^{\mathrm{bc}} \\
(4.183)\end{array}$ & $\begin{array}{l}1.115^{\mathrm{ab}} \\
(0.304)\end{array}$ & $\begin{array}{l}44.320^{\mathrm{b}} \\
(16.486)\end{array}$ & $\begin{array}{l}184.125^{\mathrm{b}} \\
(101.091)\end{array}$ \\
\hline No yeast lees 228 & $\begin{array}{l}11.778^{b} \\
(0.470)\end{array}$ & $\begin{array}{l}18.395^{\mathrm{a}} \\
(0.518)\end{array}$ & $\begin{array}{c}11.866^{\text {cdef }} \\
(2.295)\end{array}$ & \& & $\begin{array}{l}42.039^{b} \\
(2.248)\end{array}$ & - \\
\hline 1 x Yeast lees 228 & $\begin{array}{c}18.576^{\mathrm{ab}} \\
(1.383)\end{array}$ & $\begin{array}{l}6.669^{\text {cde }} \\
(3.936)\end{array}$ & $\begin{array}{c}11.456^{\mathrm{def}} \\
(0.515)\end{array}$ & \& & $\begin{array}{l}36.701^{b} \\
(4.804)\end{array}$ & - \\
\hline $1.5 \times$ Yeast lees 228 & $\begin{array}{c}21.184^{\mathrm{ab}} \\
(2.354)\end{array}$ & $\begin{array}{c}7.340^{\text {bcde }} \\
(4.057)\end{array}$ & $\begin{array}{c}11.792^{\text {cdef }} \\
(2.645)\end{array}$ & 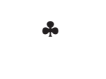 & $\begin{array}{l}40.316^{b} \\
(9.057)\end{array}$ & - \\
\hline 2 x Yeast lees 228 & $\begin{array}{c}25.109^{\mathrm{ab}} \\
(0.074)\end{array}$ & $\begin{array}{c}5.483^{\text {cde }} \\
(0.504)\end{array}$ & $\begin{array}{c}15.091^{b c d} \\
(3.711)\end{array}$ & $*$ & $\begin{array}{l}45.683^{b} \\
(4.141)\end{array}$ & - \\
\hline No yeast lees VIN 13 & $\begin{array}{c}19.275^{\mathrm{ab}} \\
(0.704)\end{array}$ & $\begin{array}{l}9.880^{b c} \\
(6.278)\end{array}$ & $\begin{array}{c}14.326^{\text {bcde }} \\
(0.248)\end{array}$ & * & $\begin{array}{l}43.481^{b} \\
(5.326)\end{array}$ & - \\
\hline 1 x Yeast lees VIN 13 & $\begin{array}{c}21.382^{\mathrm{ab}} \\
(0.190)\end{array}$ & $\begin{array}{c}7.214^{\text {bcde }} \\
(0.730)\end{array}$ & $\begin{array}{l}19.913^{\mathrm{b}} \\
(5.991)\end{array}$ & * & $\begin{array}{c}48.509^{b} \\
(6.532)\end{array}$ & - \\
\hline 1.5 x Yeast lees VIN 13 & $\begin{array}{c}25.468^{a b} \\
(1.655)\end{array}$ & $\begin{array}{c}8.087^{\text {bcde }} \\
(0.465)\end{array}$ & $\begin{array}{l}19.361^{b} \\
(1.529)\end{array}$ & * & $\begin{array}{c}52.916^{\mathrm{ab}} \\
(0.340)\end{array}$ & - \\
\hline 2 x Yeast lees VIN 13 & $\begin{array}{c}33.412^{\mathrm{ab}} \\
(3.743)\end{array}$ & $\begin{array}{c}13.617^{\mathrm{ab}} \\
(2.874)\end{array}$ & $\begin{array}{l}30.089^{\mathrm{a}} \\
(3.398)\end{array}$ & $*$ & $\begin{array}{c}77.118^{\mathrm{a}} \\
(10.015)\end{array}$ & - \\
\hline
\end{tabular}

s, small-scale distillation; L, large-scale distillation; -P, no pectolytic enzyme; +P, with pectolytic enzyme.

With large-scale distillation only yeast strain 228 (commonly used in the industry) was used.

Treatments with the same superscript do not differ significantly $(\mathrm{p} \geq 0.05)$.

All values represent the average of replicate data from four seasons.

All values in brackets represent the standard deviation.

*Degree of turbidity of juice after treatment (Klett-units).

*, The C18 values are representative of only the 1997 and 1998 harvest years, during which the effect of yeast lees content was not part of the experimental protocol.

$\mathrm{C}_{12}$, lauric acid

$\mathrm{C}_{14}$, myristic acid

$\mathrm{C}_{16}$, palmitic acid

$\mathrm{C}_{18}$, stearic acid. 
TABLE 6

Statistical relationships between chemical components, and brandy base wine and unmatured pot-still brandy quality.

\begin{tabular}{|c|c|c|c|}
\hline \multirow[t]{2}{*}{ Class } & \multirow[t]{2}{*}{ Component } & Brandy base wine & Spirit \\
\hline & & \multicolumn{2}{|c|}{ Correlation (r) \& significance (p) } \\
\hline \multirow[t]{7}{*}{ Esters } & Ethyl acetate & NS & $0.50(\mathrm{p}=0.010)$ \\
\hline & Ethyl butyrate & $0.46(\mathrm{p}=0.017)$ & NS \\
\hline & Ethyl caproate & $0.63(\mathrm{p}=0.001)$ & $0.47(\mathrm{p}=0.016)$ \\
\hline & Ethyl caprylate & $0.76(\mathrm{p}<0.0001)$ & NS \\
\hline & Ethyl caprate & $0.49(\mathrm{p}=0.010)$ & NS \\
\hline & Isoamyl acetate & $0.61(\mathrm{p}=0.001)$ & $0.83(\mathrm{p}<0.0001)$ \\
\hline & Hexyl acetate & $0.54(\mathrm{p}=0.004)$ & $0.73(\mathrm{p}<0.0001)$ \\
\hline \multirow[t]{5}{*}{ Higher alcohols } & isobutanol & $-0.39(\mathrm{p}=0.047)$ & $-0.69(\mathrm{p}<0.0001)$ \\
\hline & n-Butanol & $0.71(\mathrm{p}<0.0001)$ & $0.70(\mathrm{p}<0.0001)$ \\
\hline & Isoamyl alcohol & NS & $-0.70(\mathrm{p}<0.0001)$ \\
\hline & Hexanol & $-0.65(\mathrm{p}=0.0003)$ & $-0.61(\mathrm{p}=0.001)$ \\
\hline & 2-Phenyl ethanol & $-0.49(\mathrm{p}=0.011)$ & NS \\
\hline \multirow[t]{4}{*}{ Acids } & n-Butyric acid & $0.76(\mathrm{p}<0.0001)$ & NS \\
\hline & n-Caproic acid & $0.53(\mathrm{p}=0.005)$ & $0.56(\mathrm{p}=0.003)$ \\
\hline & n-Caprylic acid & $0.61(\mathrm{p}=0.0009)$ & $0.56(\mathrm{p}=0.003)$ \\
\hline & n-Capric acid & $0.61(\mathrm{p}=0.0009)$ & $0.41(\mathrm{p}=0.036)$ \\
\hline
\end{tabular}

NS, not significant

A

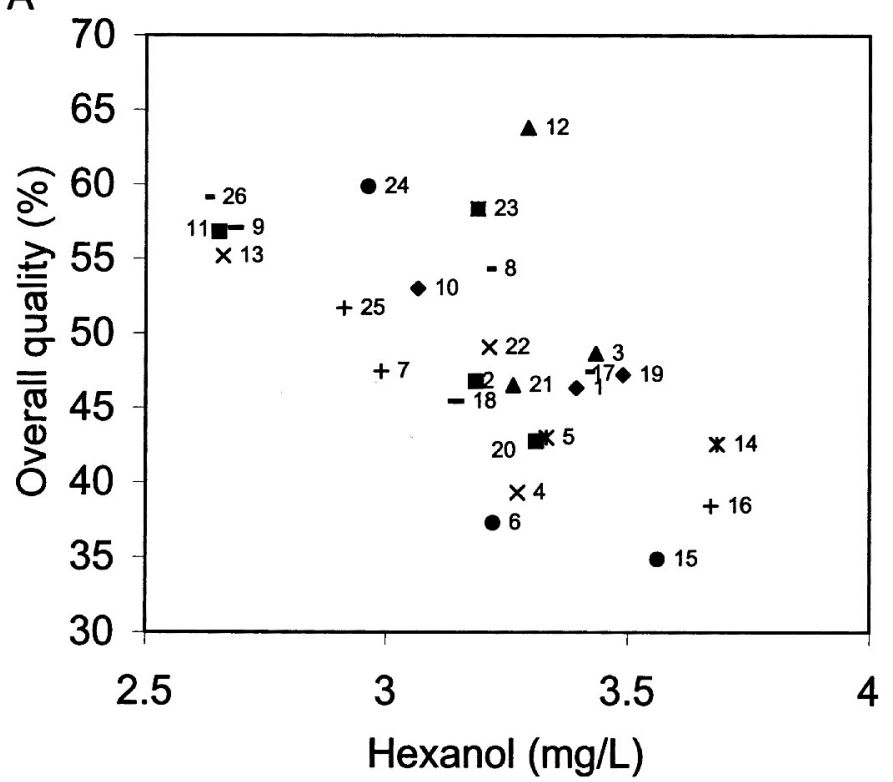

B

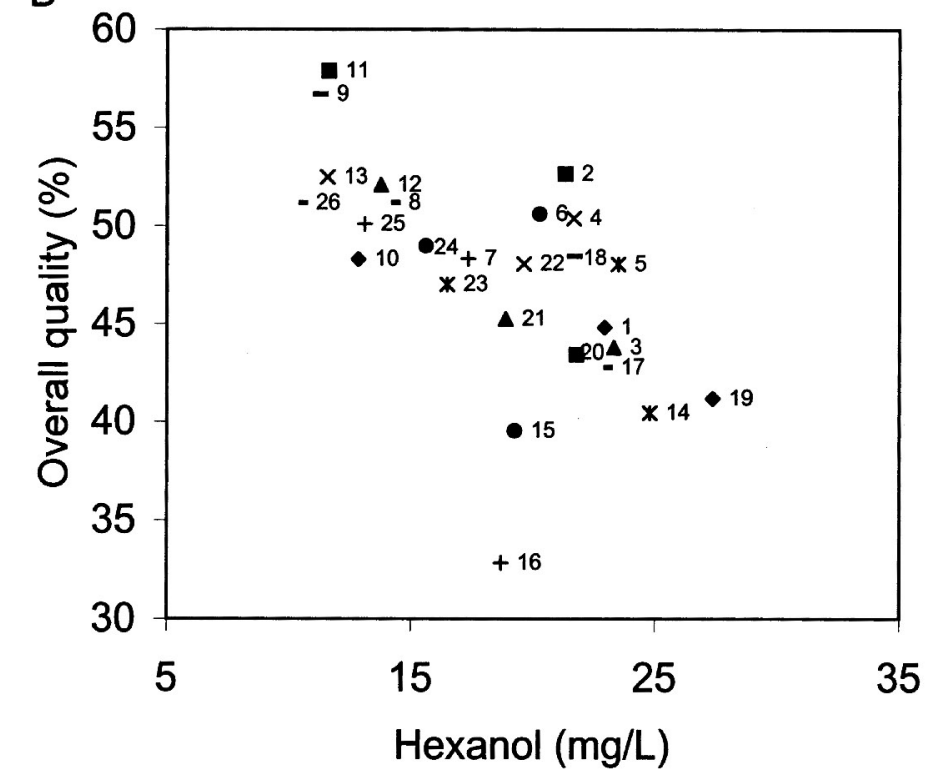

FIGURE 2

Effect of juice clarification method on hexanol concentration and overall brandy base wine (part A) and unmatured pot-still brandy (part B) quality. (A), $\mathrm{r}=-0.65$ and $\mathrm{p}$ $=0.0003$. (B), $\mathrm{r}=-0.61$ and $\mathrm{p}=0.0010$. Each symbol represents the average data of four seasons. Treatment: 1, 1.5x yeast lees $228 ; 2,1.5 \mathrm{x}$ yeast lees VIN 13; 3, 1x yeast lees 228; 4, 1x yeast lees VIN 13; 5, 2x yeast lees 228; 6, 2x yeast lees VIN 13; 7, settling (+P) 228 (L); 8, settling (+P) 228 (s); 9 , settling (+P) VIN 13 (s); 10 , settling (-P) 228 (s); 11, settling (-P) VIN 13 (s); 12, bentonite 228 (s); 13, bentonite VIN 13 (s); 14, no settling 228 (L); 15 , no settling 228 (s); 16 , no settling VIN 13 (s); 17 , no yeast lees 228; 18, no yeast lees VIN 13; 19, large-scale centrifugation 228 (L); 20, large-scale centrifugation 228 (s); 21 , large-scale centrifugation VIN 13 (s); 22 , whisk 228 (L); 23, whisk 228 (s); 24, whisk VIN 13 (s); 25, small-scale centrifugation 228 (s); 26, small-scale centrifugation VIN 13 (s). s, Small-scale distillation; $\mathrm{L}$, large-scale distillation; -P, no pectolytic enzyme and $+\mathrm{P}$, with pectolytic enzyme. 
A

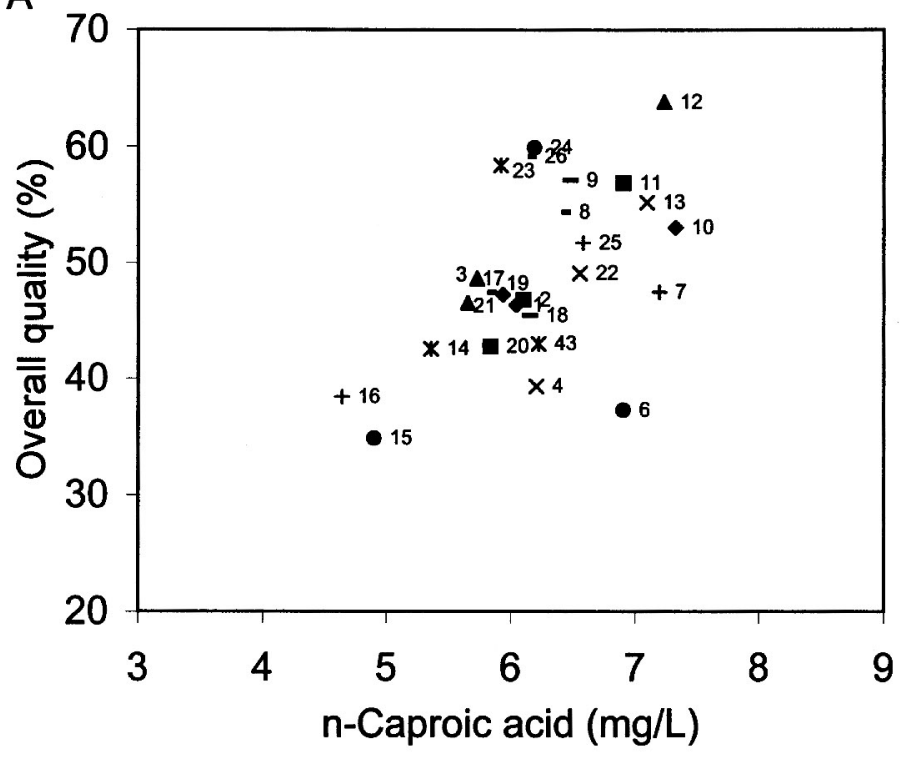

B

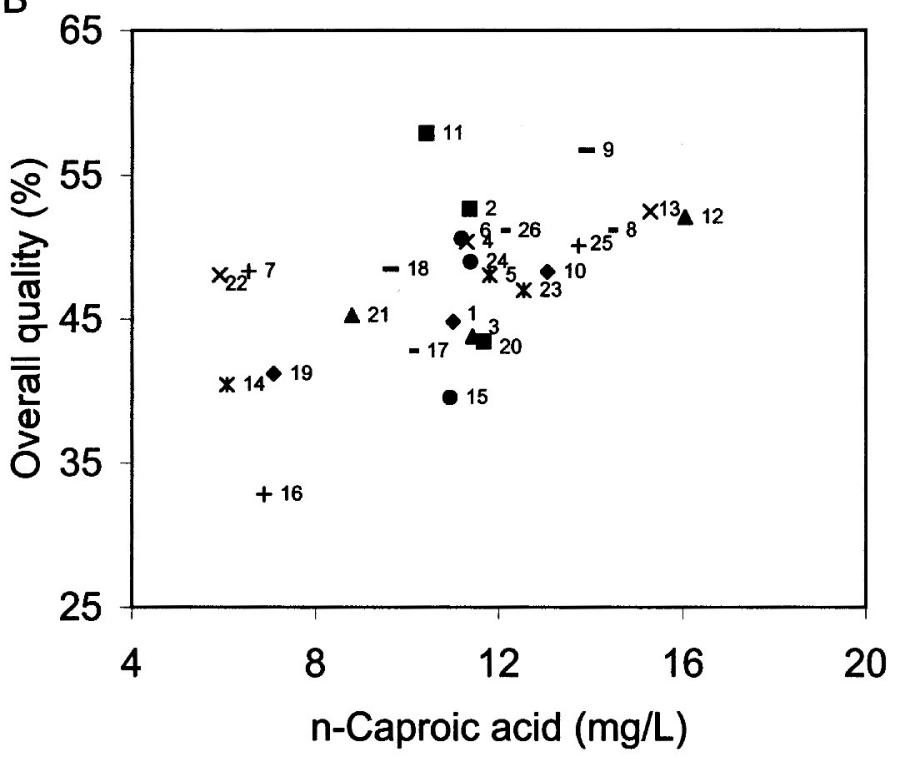

FIGURE 3

Effect of juice clarification method on $n$-caproic acid concentration and overall brandy base wine (part A) and unmatured pot-still brandy (part $\mathrm{B})$ quality. $(\mathrm{A}), \mathrm{r}=0.53$ en $\mathrm{p}=0.0052$. (B), $\mathrm{r}=0.56$ and $\mathrm{p}=0.0031$. Each symbol represents the average data of four seasons. Treatment: $1,1.5 \mathrm{x}$ yeast lees $228 ; 2,1.5 \mathrm{x}$ yeast lees VIN $13 ; 3$, 1x yeast lees 228; 4, 1x yeast lees VIN 13; 5, 2x yeast lees 228; 6, 2x yeast lees VIN 13; 7, settling (+P) $228(\mathrm{~L})$; 8 , settling (+P) 228 (s); 9 , settling (+P) VIN 13 (s); 10 , settling (-P) 228 (s); 11, settling (-P) VIN 13 (s); 12, bentonite 228 (s); 13, bentonite VIN 13 (s); 14, no settling 228 (L); 15 , no settling 228 (s); 16 , no settling VIN 13 (s); 17, no yeast lees 228; 18, no yeast lees VIN 13; 19, large-scale centrifugation 228 (L); 20, large-scale centrifugation 228 (s); 21 , large-scale centrifugation VIN 13 (s); 22, whisk 228 (L); 23, whisk 228 (s); 24, whisk VIN 13 (s); 25, small-scale centrifugation 228 (s); 26, small-scale centrifugation VIN 13 (s). s, Small-scale distillation; L, large-scale distillation; -P, no pectolytic enzyme and $+\mathrm{P}$, with pectolytic enzyme.

Similar to reported findings (Crowell \& Guymon, 1969), the concentrations of free fatty acids in unmatured pot-still brandy (except for n-caprylic acid) were quite comparable with their corresponding ethyl esters (data not shown). Some esters (ethyl acetate, ethyl caproate, hexyl acetate, isoamyl acetate) displayed a positive correlation with unmatured pot-still brandy quality (see Figure 1). The positive relationship between quality and concentrations of ethyl esters like ethyl caproate, ethyl caprylate, ethyl caprate and lauric acid can be explained by considering the characteristic aroma profiles of each. Ethyl caproate is relatively aromatic and characteristically suggestive of banana oil. Ethyl caprylate is less aromatic, more pungent, but also more intense and suggestive of crude grape fusel oil. Ethyl caprate is lighter, less intense and more fatty. Ethyl laurate is the least aromatic, with a fatty candlelike aroma. Combined, the esters remind one of a commercial "cognac oil" (Guymon \& Crowell, 1969). Ethyl acetate forms the main ester in wine (and unmatured pot-still brandy), with concentrations mostly lower than the reported levels of 150 to $200 \mathrm{mg} / \mathrm{L}$ (Lambrechts \& Pretorius, 2000). The concentrations of esters in brandy base wine, which naturally contribute to the fermentation bouquet, were considerably higher than the reported sensory threshold values for wine (Lambrechts \& Pretorius, 2000). The concentrations of fatty acid ethyl esters are also influenced by their chain length, with a decrease in concentration as the chain length increases. Fatty acid ethyl esters with chain lengths longer than ethyl laurate are $100 \%$ retained in the cell.

It is well-known that viticultural practices, the harvesting method, transport conditions, grape condition, clarification method, wine making processes, conditions of alcoholic fermentation, type of yeast, processes of maturation, juice composition and the microbial content of grape juice can influence the chemical and sensory profiles of wine (Nykänen et al., 1968; Crowell \& Guymon, 1969; Guymon \& Crowell, 1969; Schreier et al., 1979; Shinohara, 1985; Piggot et al., 1992; Castro \& Barroso, 2000; Lambrechts \& Pretorius, 2000), thus possibly explaining variations in volatile component concentrations compared with reported values. Higher concentrations of some individual esters, higher alcohols and acids, and thus total volatile component concentrations (without acetic acid in the case of acids), were also observed in unmatured pot-still brandy in comparison to brandy base wine (data for individual components not shown). The fact that brandy base wine is prepared according to special requirements to ensure a good quality unmatured pot-still brandy (Wagener, 1986; Venter, 1991), that brandy base wine and yeast lees are distilled together, followed by yeast autolysis (Crowell \& Guymon, 1969; Guymon \& Crowell, 1969; Ibern-Gómez et al., 2000), and possible differences in reported distillation methods, can explain differences in component concentrations between undistilled and distilled beverages in this study, as well as those reported in literature. Shinohara (1985) also found a wider concentration range of volatile fatty acids in wines than was reported in literature. The absence or undetectably low concentrations of isovaleric acid, valeric acid, butyric acid and propionic acid (data of individual components not shown) in unmatured pot-still brandy in comparison with brandy base wine, which once again indicates the effect of the distillation process or conditions on the 


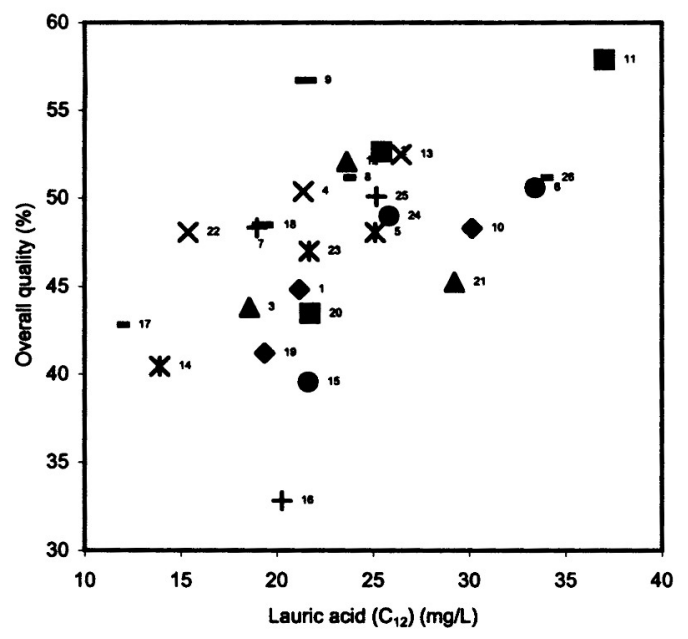

FIGURE 4

Effect of juice clarification method on lauric acid concentration and overall unmatured pot-still brandy quality. $r=0.54$ and $p=0.0045$. Each symbol represents the average data of four seasons. Treatment: 1, 1.5x yeast lees $228 ; 2,1.5 x$ yeast lees VIN 13; 3, 1x yeast lees 228; 4, 1x yeast lees VIN 13; 5, 2x yeast lees 228; 6, 2x yeast lees VIN 13; 7, settling (+P) 228 (L); 8, settling (+P) 228 (s); 9, settling (+P) VIN 13 (s); 10, settling (-P) 228 (s); 11 , settling (-P) VIN 13 (s); 12 , bentonite 228 (s); 13 , bentonite VIN 13 (s); 14, no settling 228 (L); 15, no settling 228 (s); 16, no settling VIN 13 (s); 17, no yeast lees 228; 18, no yeast lees VIN 13; 19, large-scale centrifugation 228 (L); 20, large-scale centrifugation 228 (s); 21, large-scale centrifugation VIN 13 (s); 22, whisk 228 (L); 23, whisk 228 (s); 24 , whisk VIN 13 (s); 25, small-scale centrifugation 228 (s); 26, small-scale centrifugation VIN 13 (s). s, Small-scale distillation; L, large-scale distillation; -P, no pectolytic enzyme and +P, with pectolytic enzyme.

concentration/composition of components, was also reported by other authors (Guymon \& Crowell, 1969). Although the raw material also contains esters, the primary source of long-chain esters in alcoholic beverages is the yeast cells themselves. Ethyl esters with a molecular mass greater than that of ethyl caprylate are normally bound securely to the yeast cell and are not found freely in solution (Calull et al., 1991), but may be released during a physical process such as increase in temperature during distilling (Guymon \& Crowell, 1969). It is for this reason that longchain fatty acids are only reported for unmatured pot-still brandy (see Table 5) and not for brandy base wine. Calull et al. (1991) was also unable to detect lauric acid in the grape musts or yeast cells at any stage of fermentation.

It is known that the technological processes applied to grape musts can bring about variations in fatty acid content and that the clarification of wine/musts can lead to a decrease in fatty acid content, and can consequently cause slower fermentations (Lambrechts \& Pretorius, 2000). The fact that bentonite swells considerably and does not settle (Waters et al., 2000) reflects in the degree of turbidity, with bentonite leading to more turbid musts than settling with and without pectolytic enzyme and small-scale centrifugation (see Table 3). Although clarification in general, as well as bentonite clarification of musts, can lead to removal of fatty acids and consequently slow fermentations (Weiss \& Bisson, 2002), as well as removal of wine aroma components, and therefore, lower quality wine (Dupin et al., 2000), clarification as a whole and bentonite treatment in this study led to high concentrations of fatty acids and good quality products. It is known that the clarification method and consequent turbidity/clarification of musts have an influence on the fermentation rate and acetic acid concentration of wines (Boivin et al., 1998). In this study, no settling generally yielded not only the most tur- bid juice and lowest quality wines, but resulted in of the highest detectable acetic acid concentrations.

\section{CONCLUSIONS}

Chenin blanc and Colombar(d) are both commonly used cultivars for the preparation of brandy base wine. This study defines optimal methods using Chenin blanc. The use of specific techniques for the clarification of grape juice is recommended; all the techniques/methods used in this study led to higher quality brandy base wines and unmatured pot-still brandy than in the case of untreated juice. There was a definite relationship between treatment, concentrations of esters, higher alcohols and acids, turbidity of juice, and overall brandy base wine and/or unmatured potstill brandy quality. The treatments delivering clearer juice and the higher quality brandy base wine and unmatured pot-still brandy, with higher levels of certain volatile components (as well as the long-chain fatty acid, i.e. lauric acid in the case of unmatured pot-still brandy), were settling with or without pectolytic enzyme treatment, small-scale centrifugation, bentonite treatment and whisking, and are therefore highly recommended. Whisking gave good quality brandy base wine, but the unmatured pot-still brandy was of average quality. Treatments delivering the lowest quality products were no settling and large-scale centrifugation and, as such are not recommended. The use of yeast strain VIN13 (as opposed to strain 228) in conjunction with an increased yeast lees content of $1.5 x$ normally found in brandy base wine is recommended for the best quality unmatured pot-still brandy. The scale of distillation does not impact significantly on brandy base wine or unmatured pot-still brandy quality and the results of this study can, therefore, also be applied to commercial-scale operations, keeping in mind that, compared with the brandy base wine, the unmatured pot-still brandy is closest to the final brandy, and that the results of this experiment did not follow through to the 
effects after three years of wood maturation - which is when the quality of the resultant brandy is ultimately determined.

\section{LITERATURE CITED}

Blade, W.H. \& Boulton, R., 1988. Adsorption of protein by bentonite in a model wine solution. Am. J. Enol. Vitic. 39 (3), 193-199.

Boivin, S., Feuillat, M., Alexander, H. \& Charpentier, C., 1998. Effect of must turbidity on cell wall porosity and macromolecule excretion of Saccharomyces cerevisiae cultivated on grape juice. Am. J. Enol. Vitic. 49 (3), 325-332.

Calull, M., Borrull, F., Marce, R.M. \& Zamora, F., 1991. HPLC analysis of fatty acids in wine. Am. J. Enol. Vitic. 42 (3), 268-273.

Castro, R. \& Barroso, C.G., 2000. Behavior of a hyperoxidised must during biological aging of Fino sherry wine. Am. J. Enol. Vitic. 51 (2), 98-102.

Crowell, E.A. \& Guymon, J.F., 1969. Studies of caprylic, capric, lauric and other free fatty acids in brandies by gas chromatography. Am. J. Enol. Vitic. 20 (3), 155163.

Di Cesare, L.F., Vitali, S. \& Nani, R., 1991. Application of apolar resin for the improvement of the organoleptic quality of the aromatic distillate of golden delicious apple. Fruit processing 1 (9), 142-143.

Dupin, I.V.S., McKinnon, B.M., Ryan, C., Boulay, M., Markides, A.J., Jones, G.P., Williams, P.J. \& Waters, E.J., 2000. Saccaromyces cereviseae mannoproteins that protect wines from protein haze: their release during fermentation and lees contact and a proposal for their mechanism of action. J. Agric. Food Chem. 48, 3098-3105.

Gökmen, V., Acar, J. \& Kahraman, N., 2003. Influence of conventional clarification and ultrafiltration on the phenolic composition of golden delicious apple juice. J. Food Quality 26, 257-266.

Gómez-Plaza, E., Gil-Muňoz, R., López-Roca, J. M., Martínez-Cutillas, A. \& Fernández-Fernández, J. I., 2002. Maintenance of colour composition of a red wine during storage. Influence of prefermentative practices, maceration time and storage. Lebensm.-Wiss. U. Technol. 35, 46-53.

Görtges, S. \& Haubrich, H., 1992. Fining agents and their effects on the treatment of fruit juice and wine. Fruit processing 2 (8), 119-122.

Guymon, J.F. \& Crowell, E.A., 1969. Gas chromatographic determination of ethyl esters of fatty acids in brandy or wine distillates. Am. J. Enol. Vitic. 20 (2), 76-85.

Hamatschek, J. \& Nagel, B., 1993. 100 Years of centrifuge engineering and the use of decanters for de-juicing of fruit. Fruit Processing 3 (5), 163-167.

Ibern-Gómez, M., Andrés-Lacueva, C., Lamuela-Raventós, R.M., Buxederas, S., Singleton, V.L. \& de la Torre-Boronat, M.C., 2000. Browning of cava (sparkling wine) during aging in contact with lees due to the phenolic composition. Am. J. Enol. Vitic. 51 (1), 29-36.

Israel, S. \& Leufstedt, G., 1993. Centrifugal juice extraction. Fruit Processing 3 (5), 172-175.

Kern, M., Guldenfels, W. \& Sleveke, E., 1993. The use of decanters in modern fruit and vegetable extraction. Fruit Processing 3 (5), 168-171.

Kotseridis, Y., Anocibar Beloqui, A., Bertrand, A. \& Doazan, J. P., 1998. An analytical method for studying the volatile compounds of Merlot noir clone wines. Am. J. Enol. Vitic. 49 (1), 44-48.

Lambrechts, M.G. \& Pretorius, I.S., 2000. Yeast and its importance to wine aroma - a review. S. Afr. J. Enol. Vitic. 21 (special issue), 97-129.
Lau, M.N., Ebeler, J.D. \& Ebeler, S.E., 1999. Gas chromatographic analysis of aldehydes in alcoholic beverages using a cysteamine derivitisation procedure. Am. J. Enol. Vitic. 50 (3), 324-333.

Léauté, R., 1990. Distillation in Alambic. Am. J. Enol. Vitic. 41, 90-103.

Marchand, S., de Revel, G. \& Bertrand, A., 2000. Approaches to wine aroma: release of aroma compounds from reactions between cysteine and carbonyl compounds in wine. J. Agric. Food Chem. 48, 4890-4895.

Mesquita, P.R., Piçarra-Pereira, M.A., Monteiro, S., Loureiro, V.B., Teixeira, A.R. \& Ferreira, R. B., 2001. Effect of wine composition on protein stability. Am. J. Enol. Vitic. 52 (4), 324-330.

Nykänen, L, Puputti, E. \& Suomalainen, H., 1968. Volatile fatty acids in some brands of whisky, cognac and rum. J. Food Sci. 33, 88-92.

Piggot, J.R., Conner, J.M., Clyne, J. \& Paterson, A., 1992. The influence of nonvolatile constituents on the extraction of ethyl esters from brandies. J. Sci. Food Agric. 59, 477-482.

Pons, M.N. \& Wild, G., 1991. Monitoring volatile components production by a gas membrane sensor during alcoholic fermentation. Fruit Processing 1 (11), 174 176.

Rabbets, T., 1989. Evaluasie van pektolitiese ensieme as afsakhulpmiddel vir druiwesap. Wynboer Tegnies 31, 8 .

Schaefer, J. \& Timmer, R., 1970. Flavor components in cognac. J. Food Sci. 35 $10-12$.

Schreier, P., Drawert, F. \& Winkler, F., 1979. Composition of neutral volatile constituents in grape brandies. J. Agric. Food Chem. 27 (2), 365-372.

Servili, M., de Stefano, G., Piacquadio, P. \& Sciancalepore, V., 2000. A novel method for removing phenols from grape must. Am. J. Enol. Vitic. 51 (4), 357361.

Shinohara, T., 1985. Gas chromatographic analysis of volatile fatty acids in wines. Agric. Biol. Chem. 49 (7), 2211-2212.

Snyders, H.J., 1989. Ingenieursaspekte van druif-/mosverkoeling. Wynboer Tegnies 31, 3-6.

Spagna, G., Barbagallo, R.N. \& Pifferi, P.G., 2000. Fining treatments of white wines by means of polymeric adjuvants for their stabilization against browning. $\mathrm{J}$. Agric. Food Chem. 48, 4619-4627.

Venter, W.P., 1991. Hoe lyk 'n goeie rabatwyn en hoe word dit berei? Wynboer Tegnies 47,4 .

Venter, W.P., 1994. Die sintuiglike beoordeling van potketelbrandewyn. Wynboer Tegnies 65, 10-12.

Wagener, G.W.W., 1986. The effect of off-flavours of distilling wines on the quality of brandy. Wynboer Tegnies 16, 5-12.

Waters, E., Dupin, I. \& Stockdale, V., 2000. A review of current knowledge on polysaccharides which "protect" against protein haze in white wine. Aust. Grapegrower \& Winemaker 438a, 13-16.

Weiss, K.C. \& Bisson, F., 2002. Effect of bentonite treatment of grape juice on yeast fermentations. Am. J. Enol. Vitic. 53 (1), 28-36.

Withy, L.M., Heatherbell, D.A. \& Fisher, B.M., 1993. Red raspberry wine - effect of processing and storage on colour and stability. Fruit Processing 3 (8), 303-307. 